\title{
The Triassic to Early Jurassic palynological record of the Tarim Basin, China
}

\author{
Jungang Peng ${ }^{1,2,3}\left(\mathbb{D} \cdot\right.$ Jianguo $\mathrm{Li}^{1} \cdot$ Wenben $\mathrm{Li}^{1} \cdot \mathrm{Sam} \mathrm{M}$. Slater ${ }^{3} \cdot$ Huaicheng $\mathrm{Zhu}^{4}$ • \\ Vivi Vajda ${ }^{3}$
}

Received: 23 November 2016 /Revised: 6 February 2017 / Accepted: 7 March 2017 /Published online: 6 June 2017

(C) The Author(s) 2017. This article is an open access publication

\begin{abstract}
The Tarim Basin, located in northwestern China, is an important oil-bearing region, and the extensive non-marine Mesozoic successions make this a key location for understanding environmental changes through the Triassic and Jurassic. Palynological analyses on samples from Lunnan-1 and Tazhong-1 drill cores from the northern and central part of the Tarim Basin reveal wellpreserved spore-pollen assemblages. Five palynological assemblages, i.e. Tarim Triassic 1 (TT1)-Tarim Triassic 4 (TT4) and Tarim Jurassic 1 (TJ1), spanning the Early Triassic to Early Jurassic were identified based on compositional changes, which are supported by ordination of samples using non-metric multidimensional scaling (NMDS). The Early Triassic assemblages possess abundant bryophytes and Densoisporites spp.-producers, which potentially represent a recovery succession follow-
\end{abstract}

This article is a contribution to the special issue "Jurassic biodiversity and terrestrial environments"

Electronic supplementary material The online version of this article (doi:10.1007/s12549-017-0279-y) contains supplementary material, which is available to authorized users.

Jianguo Li

jgli@nigpas.ac.cn

1 Nanjing Institute of Geology and Palaeontology, Chinese Academy of Sciences, Nanjing 210008, China

2 University of Chinese Academy of Sciences, Beijing 100049, China

3 Department of Palaeobiology, Swedish Museum of Natural History, 10405 Stockholm, Sweden

4 State Key Laboratory of Palaeobiology and Stratigraphy, Nanjing Institute of Geology and Palaeontology, Chinese Academy of Sciences, Nanjing 210008, China ing the end-Permian event. The Late Triassic spore-pollen assemblages are more similar to those of the North China Palynofloral Province compared to the South China Province. Based on our phytogeographic analysis, we propose that the western section of the boundary between the North and South China palynofloras should be placed at the southern margin of the Tarim Basin.

Keywords Phytogeography $\cdot$ Palaeovegetation .

Biostratigraphy · Spores and pollen · Triassic and Jurassic .

Tarim Basin

\section{Introduction}

The end-Permian and the end-Triassic mass extinctions represent two of the five major extinction events in life history (e.g. van de Schootbrugge et al. 2009; Akikuni et al. 2010; Shen et al. 2011; Sha et al. 2015 and references therein). Triassic to Early Jurassic terrestrial ecosystems are of particular interest because they saw the final recovery following the end-Permian event and underwent further changes through the end-Triassic event (e.g. Looy et al. 1999; Grauvogel-Stamm and Ash 2005; McElwain et al. 2009; Hochuli et al. 2010). In China, terrestrial Mesozoic successions are widely distributed across several sedimentary basins including the Junggar, Tarim, Ordos and Sichuan basins (e.g. Qu 1980; Qu and Wang 1986; Li et al. 2001; Carroll et al. 2010). These basins possess well-preserved plant macrofossil (e.g. Sun et al. 1995) and spore-pollen assemblages (e.g. Song et al. 2000) that can advance early Mesozoic vegetation reconstructions and further map floristic provinces of China. Investigations into Triassic-Jurassic ecosystems of the Tarim Basin (Fig. 1a, 


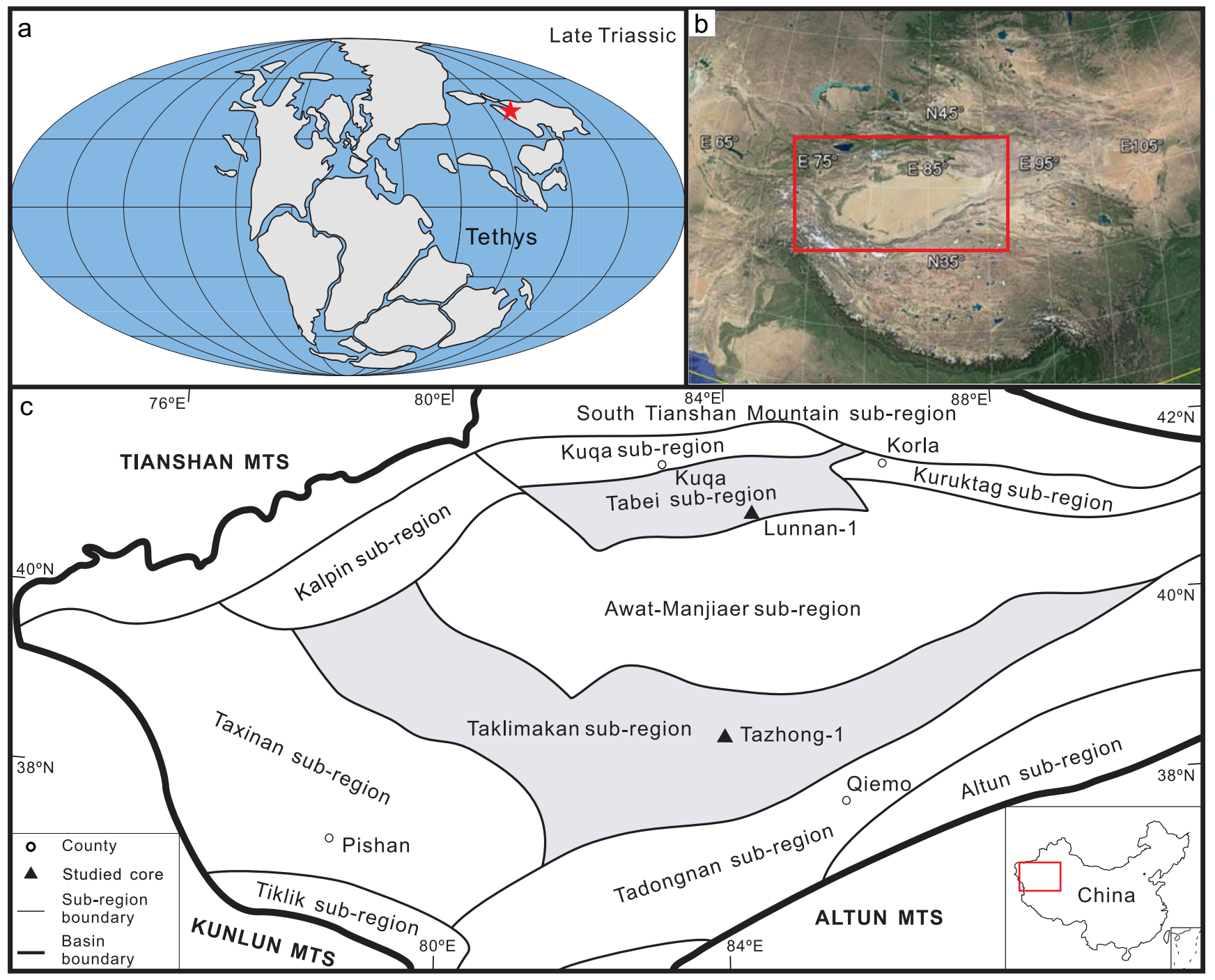

Fig. 1 a Late Triassic palaeogeography showing the position of the Tarim Basin (palaeomap from Césari and Colombi 2016; palaeolatitude of the basin from Carroll et al. 2010). b Modern geography and position

of the Tarim Basin (from Google Earth). c Schematic drawing of the geology of the Tarim Basin, showing locations of the studied wells (after Huang et al. 2002)

b) in general, and vegetational and environmental changes in particular are relatively sparse. This basin represents an important region as it lies on the margin of the North and South China palynofloral provinces. Establishing a wellresolved biostratigraphical zonation of the sedimentary successions is key in developing accurate correlations across the basin. This study aims to develop a biostratigraphical framework for the early Mesozoic successions of the Tarim Basin and to resolve the phytogeographic affinities of the palynofloras. We use spores and pollen to reconstruct the vegetation and map the Late Triassic palynofloral provinces of China with increased accuracy. Importantly, this study investigates vegetation change following the end-Permian event and across a relatively small unconformity spanning the Upper Triassic to Lower Jurassic.

\section{Geological setting and previous studies}

During the Triassic, China was composed of widely separated terranes with major blocks represented by the North China Block, the South China Block and the smaller blocks that later formed the Qinghai-Xizang Plateau. The Tarim Block was at the time part of the North China Block following its collision with the Central Asian Orogenic Belt in the Late Carboniferous and was thus incorporated into southwestern part of the Eurasia Plate (Carroll et al. 1995; Zhang et al. 2013). The Tarim Basin, located in NW China, is the country's largest sedimentary ba$\sin$. The basin is enclosed by the Tianshan Mountains to the north, the Kunlun Mountains to the southwest and the Altun Mountains to the southeast (Fig. 1c). Sedimentary successions were deposited on a crystalline basement of Archaean 
Fig. 2 Stratigraphic scheme for the subdivision of the Triassic and Jurassic strata of the Lunnan-1 core. For lithological details, see Fig. 3

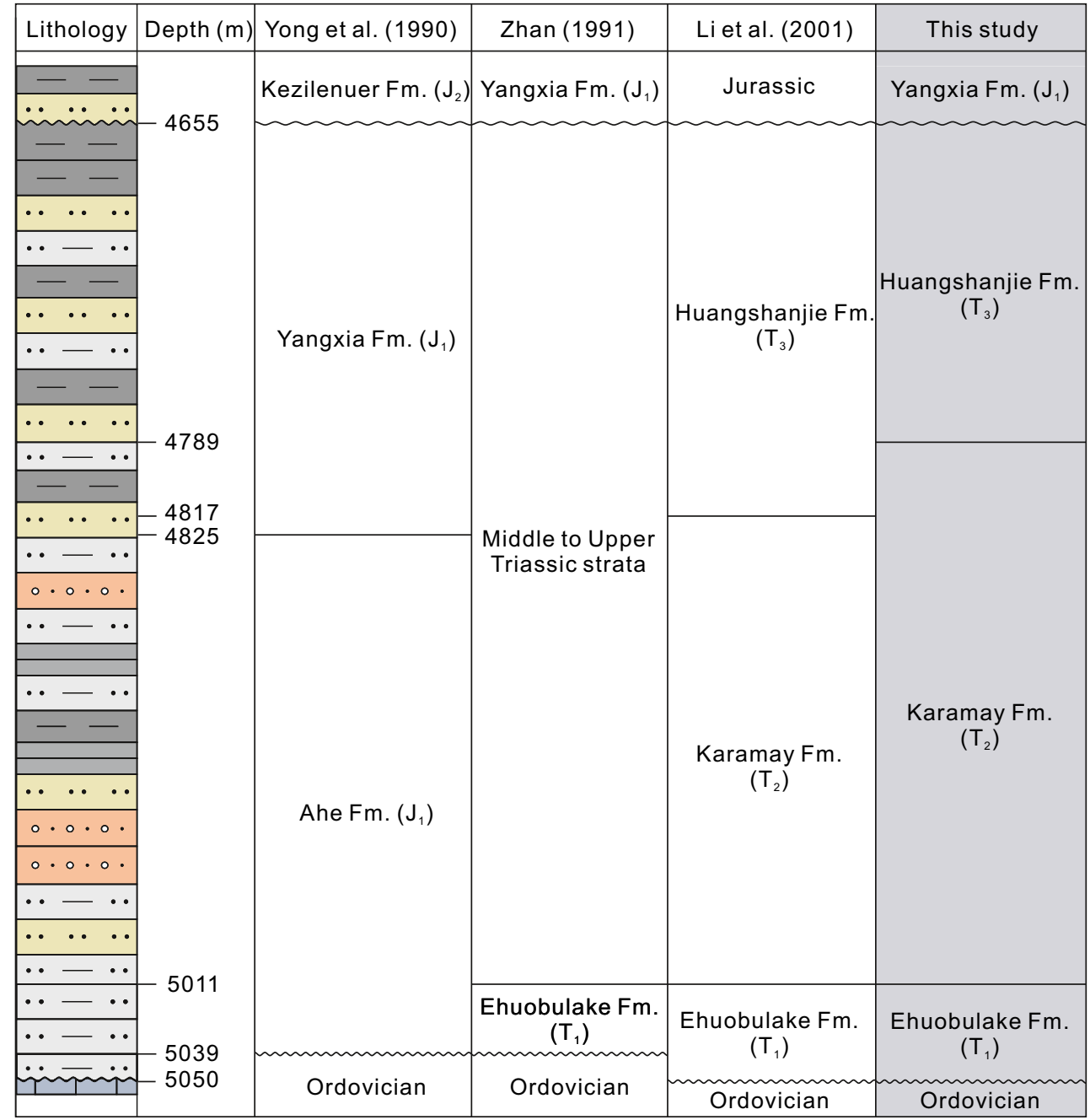

and Proterozoic metamorphic complexes (Wang et al. 1992). Following four marine transgressions and regressions prior to the Late Permian, the basin subsided passively during the Late Permian to form an intracontinental basin (Kang and Kang 1996). With the exception of Upper Permian strata, the majority of the Palaeozoic successions are marine, and the Mesozoic and Cenozoic sequences are dominantly non-marine (Zhang et al. 2000). The Tarim Basin has been subdivided based on regional stratigraphy and tectonic features (e.g. Wang et al. 1992). Huang et al. (2002) provided a composite regional stratigraphic classification of 11 stratigraphic sub-regions for the basin (Fig. 1c). The studied cores, Lunnan-1 and Tazhong-1, are located in the Tabei and Taklimakan sub-regions, respectively (Fig. 1c).

Triassic outcrops are distributed irregularly across the northern and southwestern margins of the basin, and subsurface strata have been recovered in northern, central and southwestern areas (Li et al. 2001). In the Tabei sub-region, Triassic successions comprise the Lower Triassic Ehuobulake Formation, the Middle Triassic Karamay Formation and the
Upper Triassic Huangshanjie Formation. Jurassic strata are represented by Lower and Middle Jurassic deposits ( $\mathrm{Li}$ et al. 2001; Cao et al. 2001). Within the Taklimakan sub-region, the Lower Triassic Ehuobulake Formation and the Middle to Upper Triassic strata are present ( $\mathrm{Li}$ et al. 2001; Cao et al. 2001).

Four formations are represented within Lunnan-1 spanning the Lower Triassic to Lower Jurassic: the Ehuobulake, Karamay, Huangshanjie and Yangxia formations (Fig. 2). The Lower Triassic Ehuobulake Formation $(5050-5011 \mathrm{~m})$ lies unconformably on Ordovician strata and is overlain by the Middle Triassic Karamay Formation (5011-4789 m). The Karamay Formation is overlain by the Upper Triassic Huangshanjie Formation $(4789-4655 \mathrm{~m})$; the latter is unconformably overlain by the Lower Jurassic Yangxia Formation.

In Lunnan-1, the lower part of the Ehuobulake Formation comprises dark-grey silty mudstones interbedded with dark-grey mudstones and light-grey sandy limestones. The upper part of the formation is composed of grey sandstones and conglomerates interbedded with 
Fig. 3 Lithostratigraphical profiles of Lunnan-1 and Tazhong-1 cores, with sampling levels. $T_{l} e$ the Ehuobulake Formation, $J_{l} y$ the Yangxia Formation

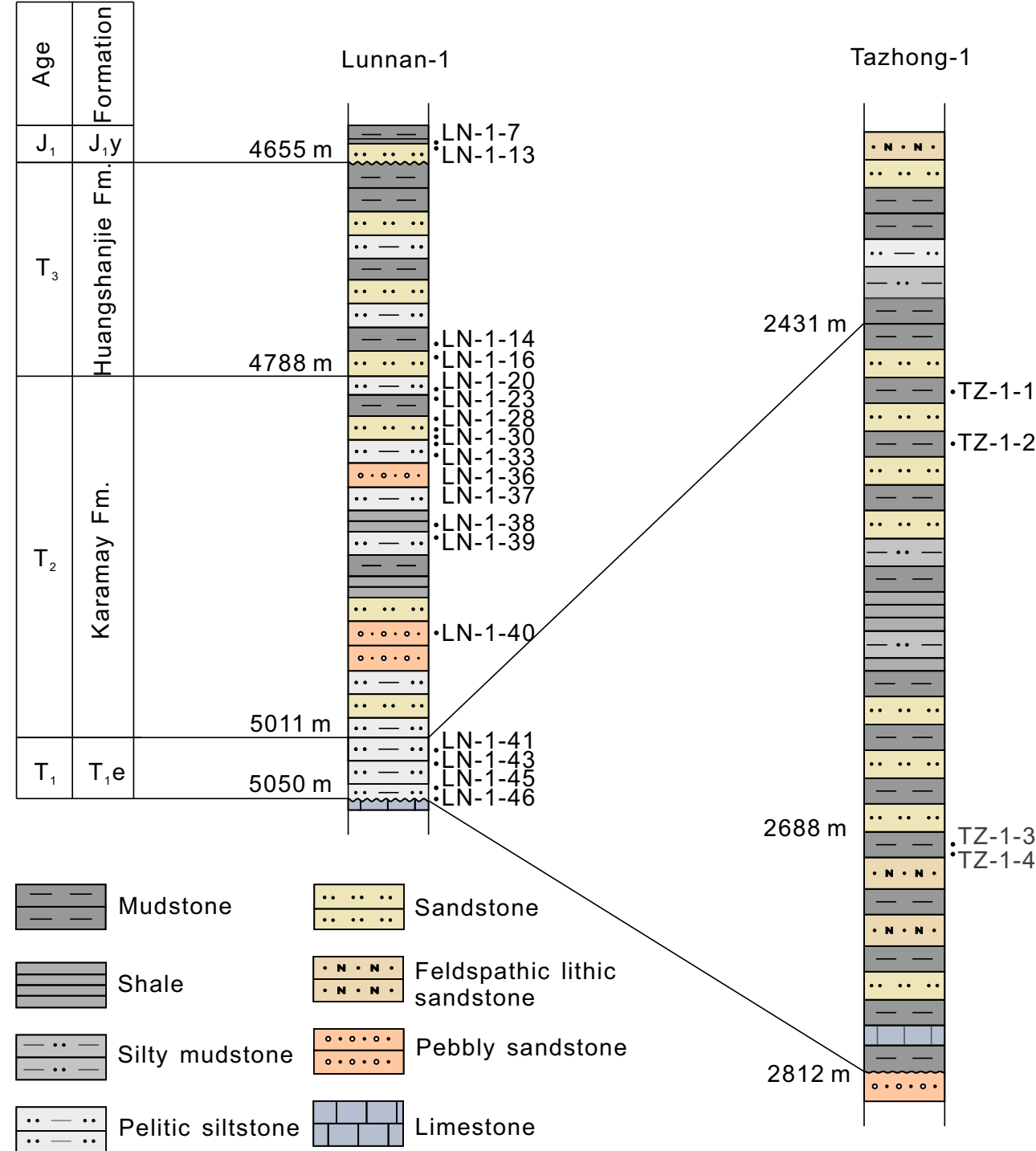

fine-grained grey sandstones. The lower part of the Karamay Formation comprises interbedded dark-grey mudstones, siltstones, fine-grained sandstones and conglomerates. The upper part of the Karamay Formation is composed of dark-grey sandy mudstones, shales, siltstones and lightgrey conglomerates. The Huangshanjie Formation is represented by fine-grained grey sandstones interbedded with sandstones and conglomerates in the basal part. The upper part of the Huangshanjie Formation is characterised by grey-black and dark-pink mudstones interbedded with fine-grained light-grey siltstones. The Lower Jurassic Yangxia Formation is composed of grey-black mudstones interbedded with fine-grained light-grey sandstones and conglomerates (Fig. 3). Miospores and megaspores have been recovered from all of these formations (Zhan 1991; Li
Fig. 4 Major pollen and spore representatives recovered from the studied cores. For all figured specimens, the sample number, slide number and England Finder coordinates are given (separated by "/"). Scale bar $=20 \mu \mathrm{m}$. a Biretisporites potoniaei Delcourt and Sprumont, 1955, LN-1-16/2/N-40-3. b Leiotriletes directus Balme and Hennelly, 1956, LN-1-16/5/L-44-3. c Leiotriletes adnatus (Kosanke) Potonié and Kremp, 1955, LN-1-41/3/S-34-1. d Calamospora mesozoica Couper, 1958, LN-1-36/2/J-44-4. e, f Calamospora impexa Playford, 1965: e LN-1-41/4/L-37-3 and f LN-1-45/5/R-32-2. g Cyathidites australis Couper, 1953, LN-1-30/3/H-38-3. h, i Concavisporites toralis (Leschik, 1955) Nilsson, 1958: h LN-1-16/3/L-31-3 and i LN-1-36/1/N-30-2. j, k Dictyophyllidites harrisii Couper, 1958: j LN-1-36/1/N-41-1 and k LN-116/4/H-36-1. I Punctatisporites punctatus Ibrahim, 1933, LN-1-43/4/Q38-1. m Todisporites concentricus Li, 1981, LN-1-43/3/S-39-2. n Retusotriletes simplex Naumova, 1953, LN-1-41/4/S-44-3. o Retusotriletes mesozoicus Klaus, 1960, LN-1-39/1/J-35-3. p Osmundacidites speciosus (Verb.) Zhang, 1965, LN-1-30/3/H-39-3. q-s Baculatisporites comaumensis (Cookson) Potonié, 1956: q LN-1-7/1/W36-1, r LN-1-36/3/G-40-3 and s LN-1-36/2/T-40-1 

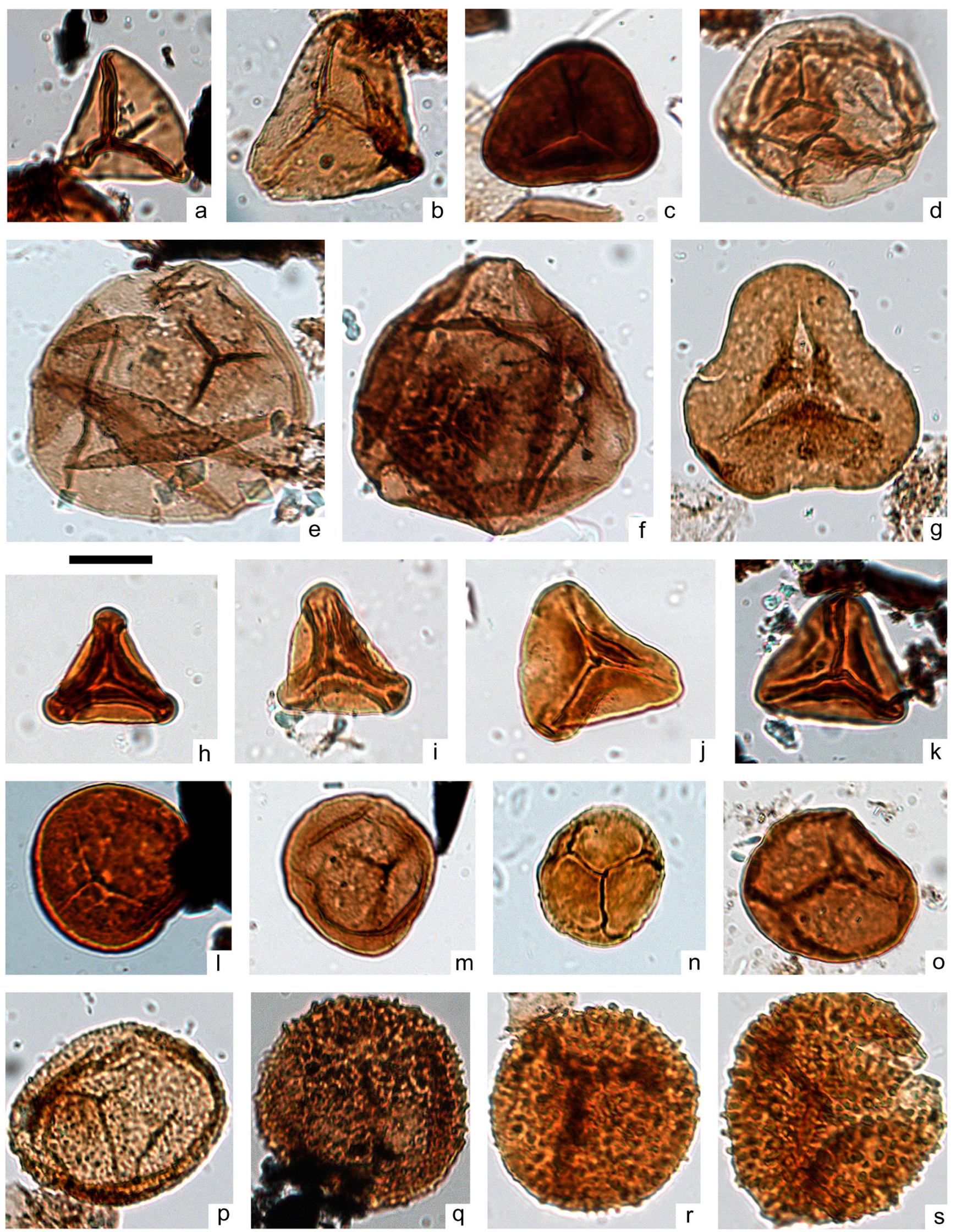

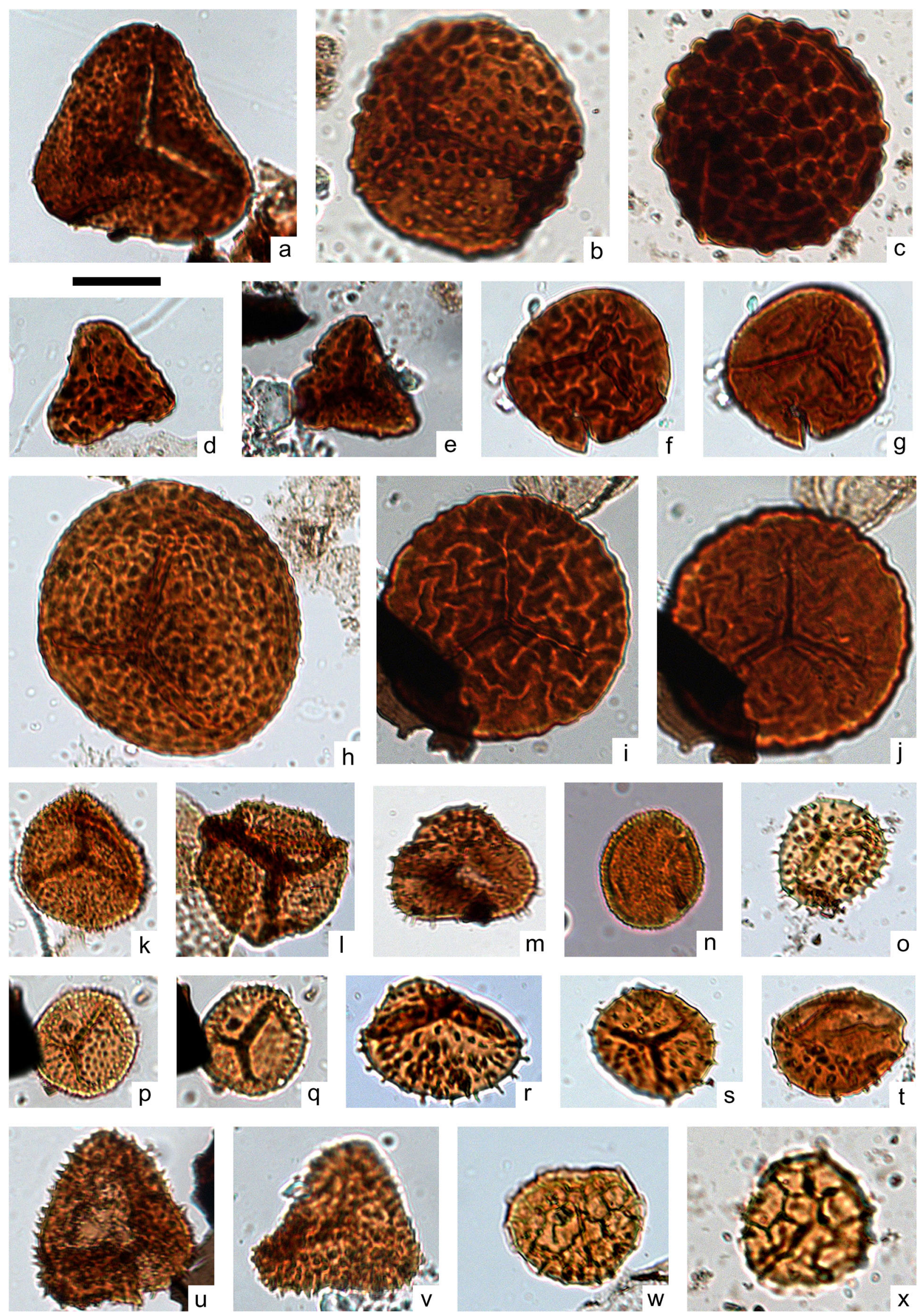
Fig. 5 Major pollen and spore representatives recovered from the studied cores. For all figured specimens, the sample number, slide number and England Finder coordinates are given (separated by "/"). Scale bar $=20 \mu \mathrm{m}$. a Converrucosisporites parviverrucosus Shang, 1981, LN-1-14/3/T-37-3. b Verrucosisporites presselensis (Schulz) Qu, 1980, LN-1-38/5/M-36-2. c Verrucosisporites morulae Klaus, 1960, LN-1-39/ 2/S-37-2. d, e Converrucosisporites dilutus $\mathrm{Pu}$ and Wu, 1985: d LN-1-14/ 4/P-38 and e LN-1-14/4/F-39. f, g Lycopodiacidites minus Lu and Wang, 1980, LN-1-23/3/R-35. h Verrucosisporites contactus Clarke, 1965, LN1-30/3/O-28. i, j Lycopodiacidites kuepperi Klaus, 1960, LN-1-7/1/Q-294. k, I Lophotriletes flavus Qu and Wang, 1986: k LN-1-30/1/P-41-3 and I LN-1-13/1/O-34-3. m Lophotriletes pseudoculeatus Potonié and Kremp, 1955, LN-1-43/5/X-43. n Apiculatisporis parvispinosus (Leschik) Qu, 1980, LN-1-23/1/X-37-3. p, q Anapiculatisporites telephorus (Pautsch) Klaus, 1960, LN-1-16/5/L-43. o, r-t Anapiculatisporites cooksonae Playford, 1965: o LN-1-40/5/T-45-1, r LN-1-30/2/P-30, s LN-1-41/4/N40-2 and t LN-1-13/4/M-36. u, v Acanthotriletes microspinosus (Ibrahim) Potonié and Kremp, 1955: u LN-1-45/4/Q-48-4 and v LN-123/5/V-37-1. w Lycopodiumsporites laevigatus (Verb.) Liu, 1981, LN-146/2/L-38-2. x Lycopodiumsporites clavatoides (Couper) Tralau, 1968, LN-1-39/2/U-33

et al. 2001), and acritarchs have been described from the lower part of the Ehuobulake Formation (Zhan 1991). Branchiopods have been recovered from the lower part of the Ehuobulake Formation and the Karamay and Huangshanjie formations (Zhan 1991).

In Tazhong-1 (Fig. 3), the Ehuobulake Formation lies unconformably on Permian strata and is overlain by the Karamay Formation from which no fossils have been recovered in this core. The Huangshanjie Formation was not recorded in Tazhong-1. The Ehuobulake Formation in Tazhong-1 is composed of dark-grey mudstones with interbedded black mudstones. The successions host miospores, megaspores and acritarchs (Li et al. 2001). The Karamay Formation comprises two lithological units: the lower portion is represented by grey-white to grey-green siltstones and grey-brown to greypurple mudstones; the upper part comprises dark-purple sandstones, greyish-purple to greyish-brown siltstones and mudstones.

Palynological studies of core Lunnan-1 include the investigations of Yong et al. (1990) and Zhan (1991). Yong et al. (1990) provided a list of taxa through the core from intervals 5039-5009.5 m (Early Triassic) and 4789-4771 (no age assignment). Zhan (1991) carried out a palynological assessment of the interval 5039-4655 m (Triassic). Li et al. (2001) documented the composition and abundance data of sporepollen assemblages of the Lunnan-1 and Tazhong-1 cores.

\section{Material and methods}

Sample preparation and data collection

A total of 22 core samples were collected for palynology: 18 from Lunnan-1 and four from Tazhong-1
(Fig. 3). Samples were prepared using standard $\mathrm{HCl}$ and $\mathrm{HF}$ palynological processing techniques in the palynological laboratory of Nanjing Institute of Geology and Palaeotology, Chinese Academy of Sciences (NIGPAS). Counts of ca. 200 specimens were carried out to produce relative abundance data. Raw count data are provided in Supplementary Table 1. Selected specimens were photographed using a Zeiss Axio microscope (Scope A1 system) under transmitted light. To improve environmental reconstructions, basic palynofacies analysis was undertaken for all samples of Lunnan-1. Black and brown woods (sensu Batten 1996; Li and Batten 2005) and miospores were counted and plotted. Counts of ca. 300 particles per sample were carried out before calculating relative abundances. Slides are stored in NIGPAS.

\section{Data analysis}

The ordination technique non-metric multidimensional scaling (NMDS) was carried out to assess compositional variation between palynological samples through time. NMDS is a non-parametric ordination technique that uses ranked distances to assess the degree of similarity between samples. In the ordination, samples that plot close together are compositionally similar and samples that plot far apart are compositionally dissimilar. The commonly used Bray-Curtis dissimilarity metric was used (e.g. Harrington 2008; Slater and Wellman 2015; Slater and Wellman 2016), and repeated runs were carried out for two dimensions until a convergent solution was established. NMDS was carried out in PAST (Hammer et al. 2001) using relative abundance (percentage) data. We also conducted correspondence analysis (CA) and detrended correspondence analysis (DCA) using the same data set. Clustering of samples in CA and DCA ordinations was highly similar to the NMDS ordination displayed here, indicating that the results are robust.

\section{Results}

Twenty samples were productive containing well-preserved miospore assemblages (Figs. 4, 5, 6, 7, 8 and 9). Based on the abundance changes of major spore and pollen groups, five palynological assemblages were identified (Figs. 10 and 11). Four are dated as Triassic and one is dated as Early Jurassic. The assemblages have been correlated to those of previous studies within the Tarim Basin (Fig. 12). Details for spore-pollen botanical affinities and correlations are provided in Supplementary Tables 2 and 3. 

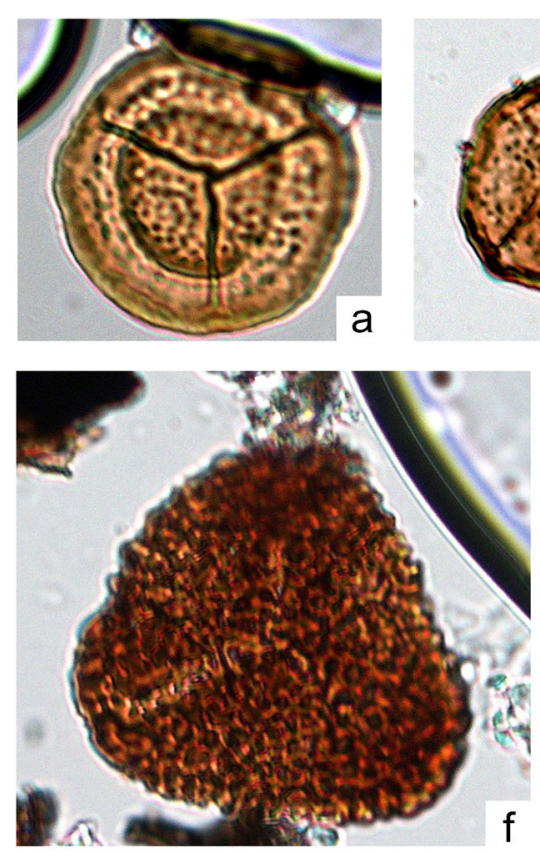
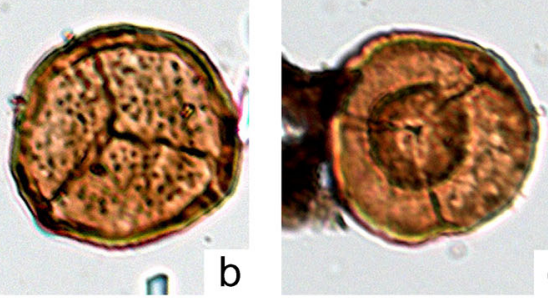
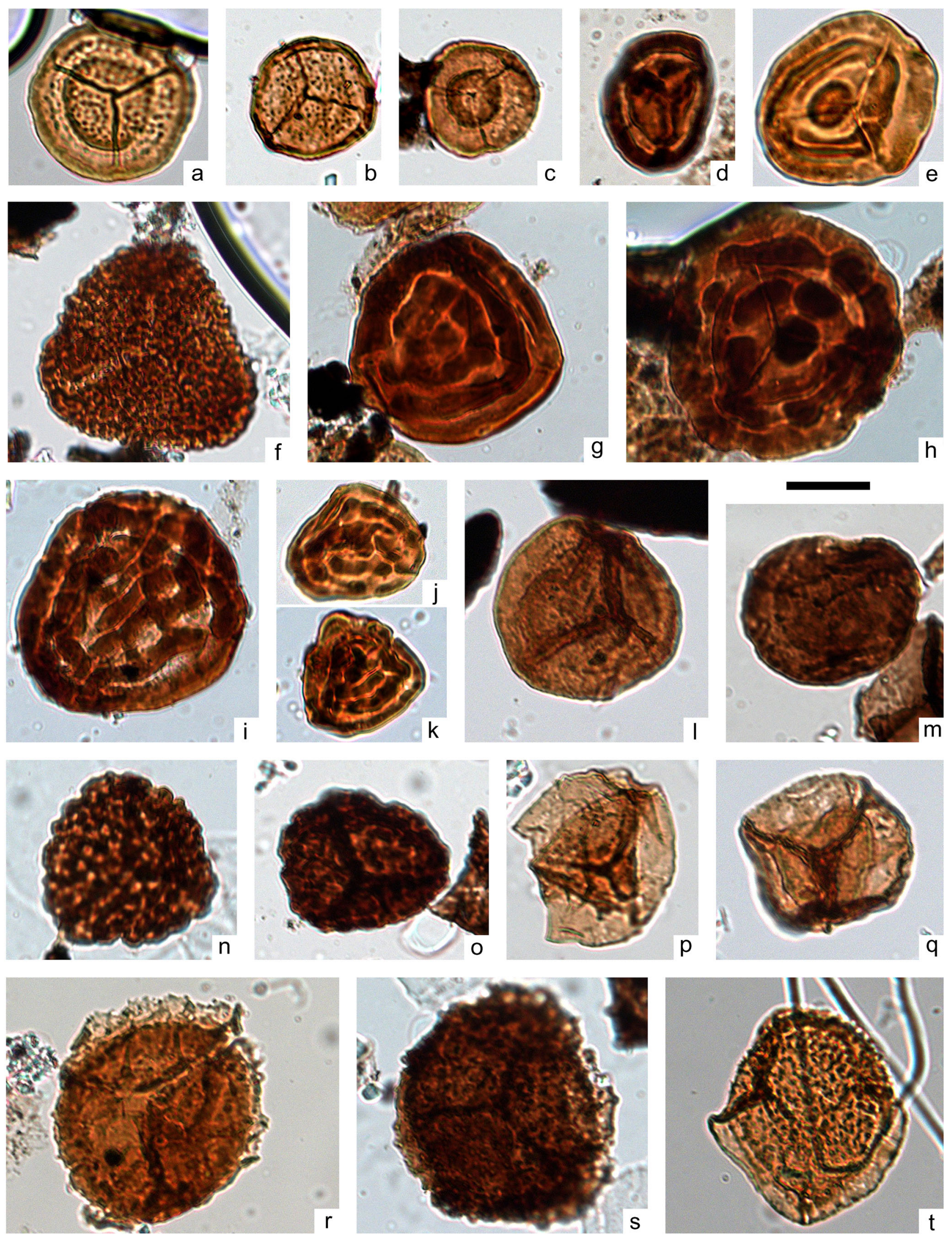
Fig. 6 Major pollen and spore representatives recovered from the studied cores. For all figured specimens, the sample number, slide number and England Finder coordinates are given (separated by "/"). Scale bar $=20 \mu \mathrm{m}$. a Limatulasporites limatulus (Playford) Helby and Foster, 1979, LN-1-46/1/J-36-2. b Nevesisporites vallatus De Jersey and Paten, 1964, LN-1-43/1/P-42-1. c Annulispora microannulata De Jersey, 1962, LN-1-43/1/V-41. d Annulispora planula Lu and Wang, 1980, LN-1-39/2/ R-32. e Polycingulatisporites irregularis (Korgenevskaya) Playford and Dettmann, 1965, TZ-1-1/4/Q-37. f Camptotriletes warchianus Balme, 1970, LN-1-45/1/O-36-1. g Striatella seebergensis Mädler, 1964, LN-114/4/P-41-2. h Asseretospora amplectiformis (Kara-Murza) Qu and Wang, 1990, LN-1-23/4/V-44-3. i Striatella scanicus (Nilsson) Filatoff and Price, 1988, LN-1-23/2/O-42-2. j, k Striatella sp.: j LN-1-7/1/P-37-4 and $\mathbf{k}$ LN-1-7/5/Q-34-1. 1, m Densoisporites playfordii (Balme) Dettmann, 1963: I TZ-1-1/4/K-29-4 and m LN-1-43/5/O-39-2. n, o Densoisporites foveotus Qu and Wang, 1986: n LN-1-41/2/E-40-4 and o LN-1-43/2/X-45-1. p, q Lundbladispora variabilis (Jansonius) Qu and Wang, 1990: p LN-1-36/1/S-40 and q TZ-1-1/5/S-44-4. r Kraeuselisporites apiculatus Jansonius, 1962, LN-1-46/4/P-35-3. s Kraeuselisporites punctatus Jansonius, 1962, LN-1-41/4/H-43. t Kraeuselisporites sp., LN-1-23/1/N-32-4

General vegetation patterns

Spores and pollen were grouped botanically (following e.g. Rouse 1957; Delcourt et al. 1963; Couper 1958; Balme 1995; van Konijnenburg-van Cittert 1993; Batten and Dutta 1997; Song et al. 2000; Mander et al. 2010; Mander 2011; Hermann et al. 2011; Raine et al. 2011; Bonis and Kürschner 2012) to assess broad temporal vegetation changes (Supplementary Table 2). Floras comprise a mixture of bryophytes, lycophytes, sphenophytes, ferns, pteridosperms, conifers and monosulcate pollen-producers (Fig. 11). Macrofloral studies of coeval deposits from the Tarim Basin have recovered cycadophytes and ginkgophytes ( $\mathrm{Li}$ et al. 2001); thus, monosulcate pollen probably originates from a mixture of these groups.

Bryophyte, lycophyte and fern abundances vary considerably through Lunnan-1, whilst other groups remain comparatively stable (Fig. 11). Bryophytes are represented by Limatulasporites limatulus, Nevesisporites vallatus and Annulispora spp. (Fig. 10) and are abundant in the Lower Triassic strata (ca. 20\%) but become increasingly rare within the Middle and Upper Triassic successions (Fig. 11). Lycophytes are represented by Densoisporites spp., Aratrisporites spp., Lycopodiumsporites (al. Retitriletes) spp. and Anapiculatisporites spp. (Fig. 10). Lycophytes are markedly more abundant in the Middle Triassic (ca. 40\%) and are moderately more abundant in the Upper Triassic (ca. 15\%) compared to the Lower Triassic (ca. 10\%) (Fig. 11). Within this group, Aratrisporites spp. dominate in the Middle Triassic and Lycopodiumsporites spp. dominate in the Lower Jurassic (Fig. 10). Ferns are represented by Biretisporites potoniaei, Leiotriletes spp., Punctatisporites punctatus, Todisporites spp., Concavisporites toralis, Dictyophyllidites harrisii, Osmundacidites spp., Verrucosisporites spp., Apiculatisporis spp., Baculatisporites comaumensis and Striatella spp. (Fig. 10). Ferns are highly abundant throughout the section, and abundances increase from ca. $30 \%$ in the Lower Triassic and ca. $40 \%$ in the Middle Triassic to ca. $70 \%$ in the Upper Triassic. Pollen from seed ferns and conifers include taeniate bisaccate pollen, Alisporites spp. and Abietineaepollenites spp. Monosulcate pollen-producers (e.g. cycadophytes and ginkgophytes) occur consistently in low abundance through the section (Fig. 11).

Palynostratigraphy

Tarim Triassic 1 Assemblage (TT1)

Core and interval: Lunnan-1, 5050-5011 m; Tazhong-1, 2498-2437 m.

Diagnostic features: High abundances of Limatulasporites limatulus, Densoisporites spp. and Lunatisporites pellucidus. Aratrisporites spp. are rare. Fern spores are dominated by Leiotriletes spp., Punctatisporites punctatus and Osmundacidites spp.

Age assessment: The low abundance of Aratrisporites spp. and high abundances of Limatulasporites spp., Densoisporites spp. and Lunatisporites spp. all support an Early Triassic and possibly Olenekian age (e.g. Helby et al. 1987; Liu 2003).

Tarim Triassic 2 Assemblage (TT2)

Core and interval: Lunnan-1, 4948-4879 m.

Diagnostic features: Abundant Aratrisporites spp. and Calamospora mesozoica. Limatulasporites limatulus, Densoisporites spp. and Lunatisporites spp. show marked decreases in Tarim Triassic 2 (TT2). Parataeniaesporites pseudostriatus and Lycopodiacidites kuepperi are new incoming taxa.

Age assessment: Abundant Aratrisporites spp. together with a marked decline in abundances of Densoisporites spp., Limatulasporites spp. and bisaccate taeniate pollen grains are indicative of a younger age than Early Triassic, and possibly Middle Triassic (e.g. Helby et al. 1987; Qu and Wang 1986; Liu 2003). The presence of Parataeniaesporites (al. Colpectopollis spp.) indicates a Middle to Late Triassic age (Liu et al. 1981). The low abundances of Dictyophyllidites spp. and Concavisporites spp. tentatively suggest a Middle Triassic age (e.g. Qu 1980; Qu and Wang 1986). 

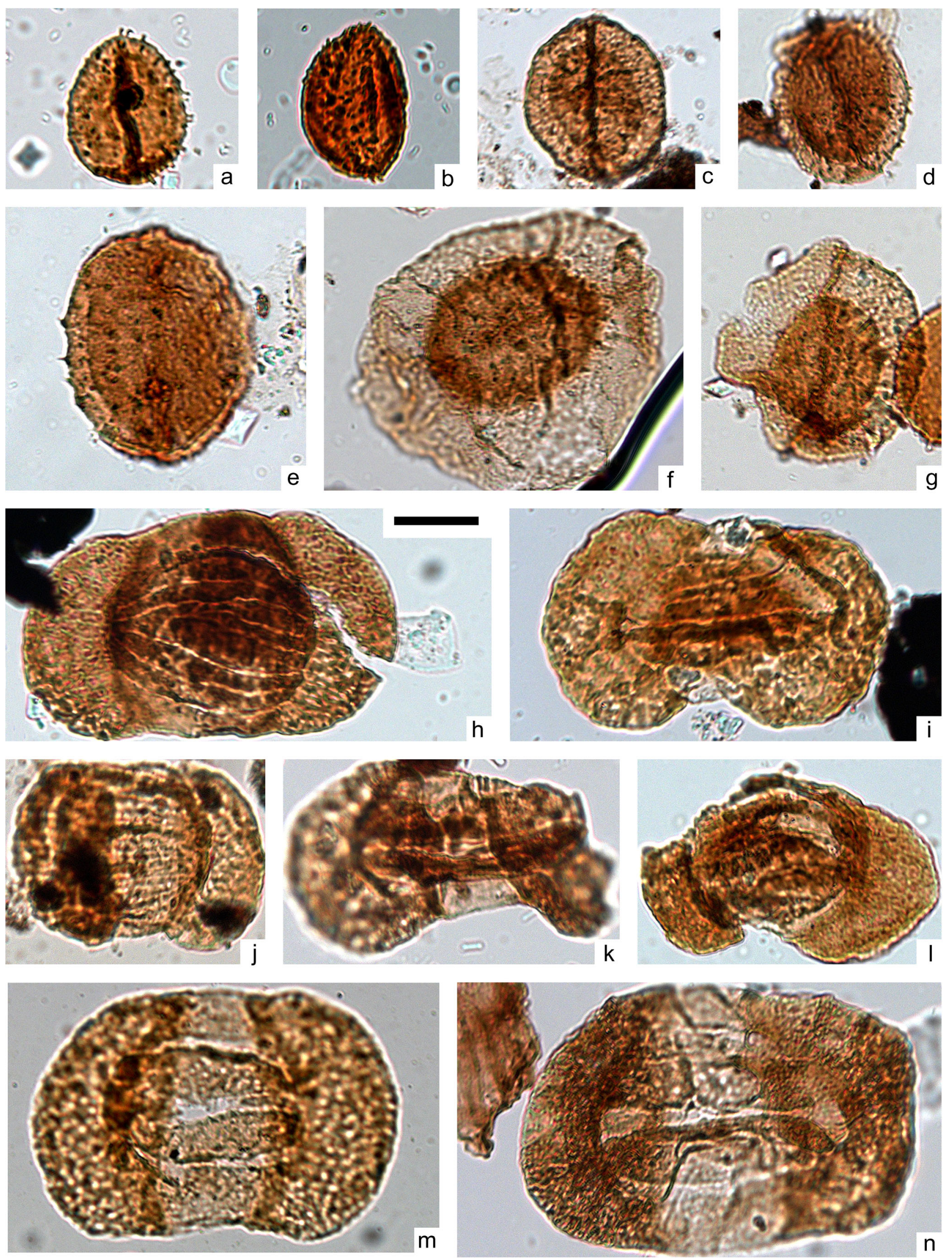
Fig. 7 Major pollen and spore representatives recovered from the studied cores. For all figured specimens, the sample number, slide number and England Finder coordinates are given (separated by "/"). Scale bar $=20 \mu \mathrm{m}$. a, b Aratrisporites paenulatus Playford and Dettmann, 1965: a LN-1-30/1/X-38-4 and b LN-1-30/1/S-33-4. c, d Aratrisporites strigosus Playford, 1965: c LN-1-40/3/H-34-1 and d LN-1-16/3/M-37. e Aratrisporites adnatus Huang, 2008, LN-1-23/5/O-31. f, g Aratrisporites fischeri (Klaus) Playford and Dettmann, 1965: f LN-1-33/4/F-33-1 and g LN-1-37/1/Q-33-1. h Protohaploxypinus dvinensis (Sedova) Hart, 1964, LN-1-41/2/N-36-2. j Striatoabieites multistriatus (Balme and Hennelly) Hart, 1964, LN-1-39/2/N-40. i, k, I Lunatisporites kraeuseli Leschik, 1955: i LN-1-46/2/N-37-2, k TZ-1-4/1/X-35-1 and I LN-1-36/3/S-39-3. m, n Lunatisporites pellucidus (Goubin) Helby, 1972: m LN-1-46/1/P38-3 and n TZ-1-1/1/V-44-1

Tarim Triassic 3 Assemblage (TT3)

Core and interval: Lunnan-1, 4840-4800 m.

Diagnostic features: Abundant Aratrisporites spp. and an increase in abundance and diversity of Striatella spp. and Apiculatisporis spp. Dictyophyllidites harrisii and Concavisporites toralis occur in low abundances.

Age assessment: Apiculatisporis spp., Acanthotriletes microspinosus, Lophotriletes spp. and Anapiculatisporites spp. are common in Middle Triassic strata and abundant in Upper Triassic strata of northern China (e.g. Qu 1980; Qu and Wang 1986; Liu 2003); Dictyophyllidites harrisii and Concavisporites toralis are abundant in Upper Triassic strata, e.g. in the Junggar (Qu and Wang 1986) and Ordos basins (Qu 1980). Based on the increase of spiny trilete spores (e.g. Apiculatisporis spp., Acanthotriletes microspinosus, Lophotriletes spp. and Anapiculatisporites spp.), the low abundance of Dictyophyllidites harrisii and Concavisporites toralis and the absence of Lunatisporites spp. and Limatulasporites spp., we interpret this assemblage as late Middle Triassic in age. It should be noted that the uppermost part of the Karamay Formation has been interpreted as Upper Triassic in previous studies (e.g. Zhang et al. 2004), however, based on the palynology of samples LN-1-23 and LN-1-20 we suggest that it is Middle Triassic.

Tarim Triassic 4 Assemblage (TT4)

Core and interval: Lunnan-1, 4782-4771 m.

Diagnostic features: Dictyophyllidites harrisii and Concavisporites toralis are abundant with moderately abundant Apiculatisporis spp. and Aratrisporites spp. Striatella spp. and Quadraeculina anellaeformis occur in low abundances. Lycopodiumsporites spp. and Cyathidites minor are present.

Age assessment: Late Triassic based on abundant Dictyophyllidites harrisii and Concavisporites toralis, as well as common Aratrisporites spp. and spiny trilete spores. This assemblage is similar to Late Triassic assemblages of North China elsewhere, e.g. the Junggar Basin (Qu and Wang 1986, 1990; Sha et al. 2011, 2015) and the Ordos Basin (Qu 1980; Liu et al. 1981). However, Zebrasporites spp. have not been recovered in this assemblage. The first occurrence of this genus was regarded as the base of Ashmoripollis reducta Oppel Zone in Australia spanning from Rhaetian to ?Hettangian (Helby et al. 1987). Thus, the lack of this genus tentatively suggests an early Late Triassic (Carnian to Norian) age for Tarim Triassic 4 (TT4).

Tarim Jurassic 1 Assemblage (TJ1)

Core and interval: Lunnan-1, 4649-4641 m.

Diagnostic features: Abundant Lycopodiumsporites spp., Dictyophyllidites harrisii, Cyathidites spp. and Pinuspollenites spp.

Age assessment: This assemblage displays high compositional similarity with the Cyathidites-CerebropollenitesPinuspollenites assemblage of Zhan (1991), specifically regarding the abundances of Lycopodiumsporites spp., Cyathidites spp. and Pinuspollenites spp. The interval 4649-4641 m of Lunnan-1 possesses the megaspores Kuqaia radiata and Kuqaia concentrica indicating an Early Jurassic age (Li 1993).

Non-metric multidimensional scaling

Ordination (Fig. 13) reveals that samples of the proposed assemblages separate well in ordination space with no overlap. This demonstrates notable compositional differences between samples of different assemblages and supports a division of five assemblages: four for the Tarim Triassic (TT1-TT4) and one for the Tarim Jurassic (TJ1). Samples from the Tazhong-1 core (Assemblage TT1) plot close to samples of same age within the Lunnan-1 core. This suggests that the parent vegetation was similar among these localities during the Early Triassic. Axis scores for the NMDS ordination are provided in Supplementary Table 4.

Palynofacies

The palynofacies of Lunnan-1 is dominated by black and brown wood remains with small quantities of other components (Fig. 11). There is little compositional variation between samples, indicating a relatively stable depositional setting. The acritarch Veryhachium sp. was recorded in LN-1-30 and LN-1-43, indicating possible marine influence. The algae Botryococcus spp. is present in most 

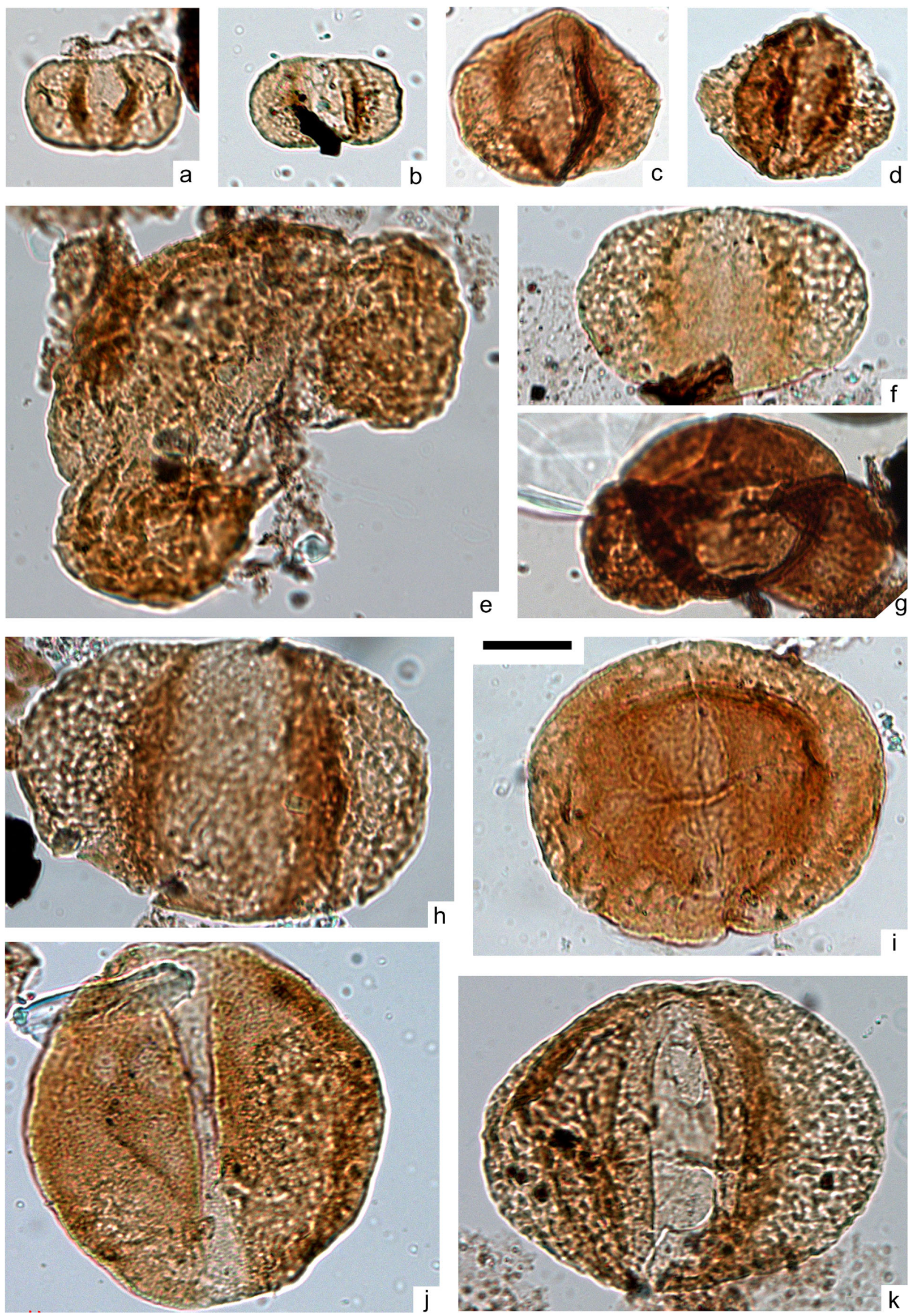
4 Fig. 8 Major pollen and spore representatives recovered from the studied cores. For all figured specimens, the sample number, slide number and England Finder coordinates are given (separated by "/"). Scale bar $=20 \mu \mathrm{m}$. a, b Vitreisporites pallidus (Reissinger) Nilsson, 1958: a LN-1-36/1/T-31-1 and b LN-1-30/1/U-31-4. c, d Klausipollenites decipiens Jansonius, 1962: c LN-1-43/1/O-34 and d LN-1-41/4/Q-43-2. e Pinuspollenites stinctus (Bolkhovitina) Shang, 1981, LN-1-33/1/J-42-4. f Abietineaepollenites minimus Couper, 1958, LN-1-46/1/J-40. g Pinuspollenites divulgatus (Bolkhovitina) Qu, 1980, LN-1-38/3/W-372. h Abietineaepollenites microalatus Potonié, 1951, LN-1-23/2/V-40-2. i Parataeniaesporites pseudostriatus (Kopytova) Liu, 1980, LN-1-23/5/ O-37. j Protoconiferus flavus Bolkhovitina, 1956, LN-1-13/1/L-33-3. k Alisporites australis De Jersey, 1962, LN-1-30/2/V-33

samples, indicating a fresh-brackish depositional setting (e.g. Batten and Grenfell 1996) (for raw palynofacies count data, see Supplementary Table 5).

\section{Discussion}

Temporal vegetation change

TT1: The earliest Triassic successions, missing from Lunnan-1, are preserved in the Taxinan sub-region (Fig. 1c), where low diversity palynological assemblages representing a transitional Permian-Triassic boundary interval were described by Zhu (1996). The TT1 vegetation of this study follows these earliest Triassic assemblages with comparably higher diversities and spore abundances. The flora of the Early Triassic assemblage (TT1) is dominated by bryophytes, ferns and conifers with taeniate bisaccate pollen-producing gymnosperms as subsidiary elements (Fig. 14). These Olenekian wetland communities are possibly a response of an allogenic succession of early pioneers represented by bryophytes and lycophytes that produced spores such as Limatulasporites limatulus and Densoisporites spp. This spore-producing vegetation was thriving globally following the end-Permian mass extinction, forming a marker for the recovery successions in continental environments (Looy et al. 1999; Grauvogel-Stamm and Ash 2005; Vajda and McLoughlin 2007; Bercovici et al. 2015).

TT2-TT3: The succeeding early Middle Triassic assemblage (TT2) continues with pollen dominance and a considerable reduction of bryophytes. Aratrisporites spp. is the dominant lycophyte genus replacing Densoisporites spp., which potentially represents a "normal" succession dynamic rather than abrupt environmental changes. Other lycophytes also emerged and, together with a broad range of ferns, formed a shadetolerant understory. The middle story comprises ginkgoes/cycads and tree ferns (e.g. Cyatheaceae), and the upper storey comprises a conifer canopy (Fig. 14). The following late Middle Triassic assemblage TT3 continues with an increase in abundances of Aratrisporites spp--producing lycophytes and monosulcate pollen-producers. Fern abundances increase slightly from TT2 into TT3 (Fig. 14). This vegetation change shows that bryophytes decreased from the Early to the Middle Triassic, and their niche was filled by the Aratrisporites spp.producers, subsequently followed by ferns. Seed ferns (represented by taeniate bisaccates) reduced markedly in the Middle Triassic (TT2-TT3) compared to the Early Triassic (TT1).

TT4: The Late Triassic assemblage (TT4) is strongly dominated by ferns, including abundant Leiotriletes spp., Dictyophyllidites harrisii and Concavisisporites toralisproducers. Conifers are slightly less abundant, and Vitreisporites pallidus-producers are markedly less abundant in TT4 compared to TT3. In summary, the vegetation change from TT2-TT3 to TT4 is characterised by a shift from an ecosystem dominated by Aratrisporites-producers (lycophytes) and conifers, to a fern-dominated ecosystem with less conifers in the Late Triassic as reflected in the TT4 assemblage.

TJ1: This Early Jurassic assemblage is characterised by high relative abundances of lycophyte (Lycopodiumsporites spp.producers) spores together with bisaccate conifer pollen, including Pinuspollenites spp. (Fig. 14). The contact between the Triassic and Jurassic strata in Lunnan-1 is unconformable, and the interval of this hiatus possibly comprises part of/all of the Rhaetian based on the age assignments of palynological assemblages provided here. Relatively limited vegetational changes are noted with respect to broad botanical groups across the Triassic-Jurassic interval; however, the spore peak (Fig. 10) in TT4 (Late Triassic) and a substantial increase in Lycopodiumsporites spp. within the Lycophyta group in TJ1 (Early Jurassic) were identified. These signals possibly

Fig. 9 Major pollen, spores and acritarchs recovered from the studied cores. For all figured specimens, the sample number, slide number and England Finder coordinates are given (separated by "/"). Scale bar $=20 \mu \mathrm{m}$. a-c Quadraeculina anellaeformis Maljavkina, 1949: a LN-1-7/1/K-28-4, b LN-1-13/2/R-32-2 and c LN-1-14/1/R-30-1. d Dacrycarpites henanensis (Ouyang and Zhang) Huang, 2008, LN-1-30/ 2/N-43. e, f Microcachryidites spp.: e LN-1-30/3/K-30-2 and f LN-1-30/ 3/E-36-3. g-i Psophosphaera minor (Verbitzkaja) Song and Zheng, 1981: g LN-1-38/1/O-34-2, h LN-1-20/5/P-30-2 and i LN-1-28/1/V-351. j, n Chasmatosporites elegans Nilsson, 1958: j LN-1-36/4/O-35 and $\mathbf{n}$ LN-1-23/4/K-35. k Monosulcites sp., LN-1-40/1/X-27. I Brevimonosulcites canadensis (Pocock) Zhang, 1978, LN-1-28/2/R-332. m Monosulcites minimus Cookson, 1947, LN-1-30/1/X-35. o, p Cycadopites sufflavus Visscher, 1966: o LN-1-14/3/V-43 and p LN-113/4/M-36-3. q Cycadopites deterius (Balme) Pocock, 1970, LN-1-39/ 5/K-35-2. r Veryhachium sp., LN-1-30/3/K-29 

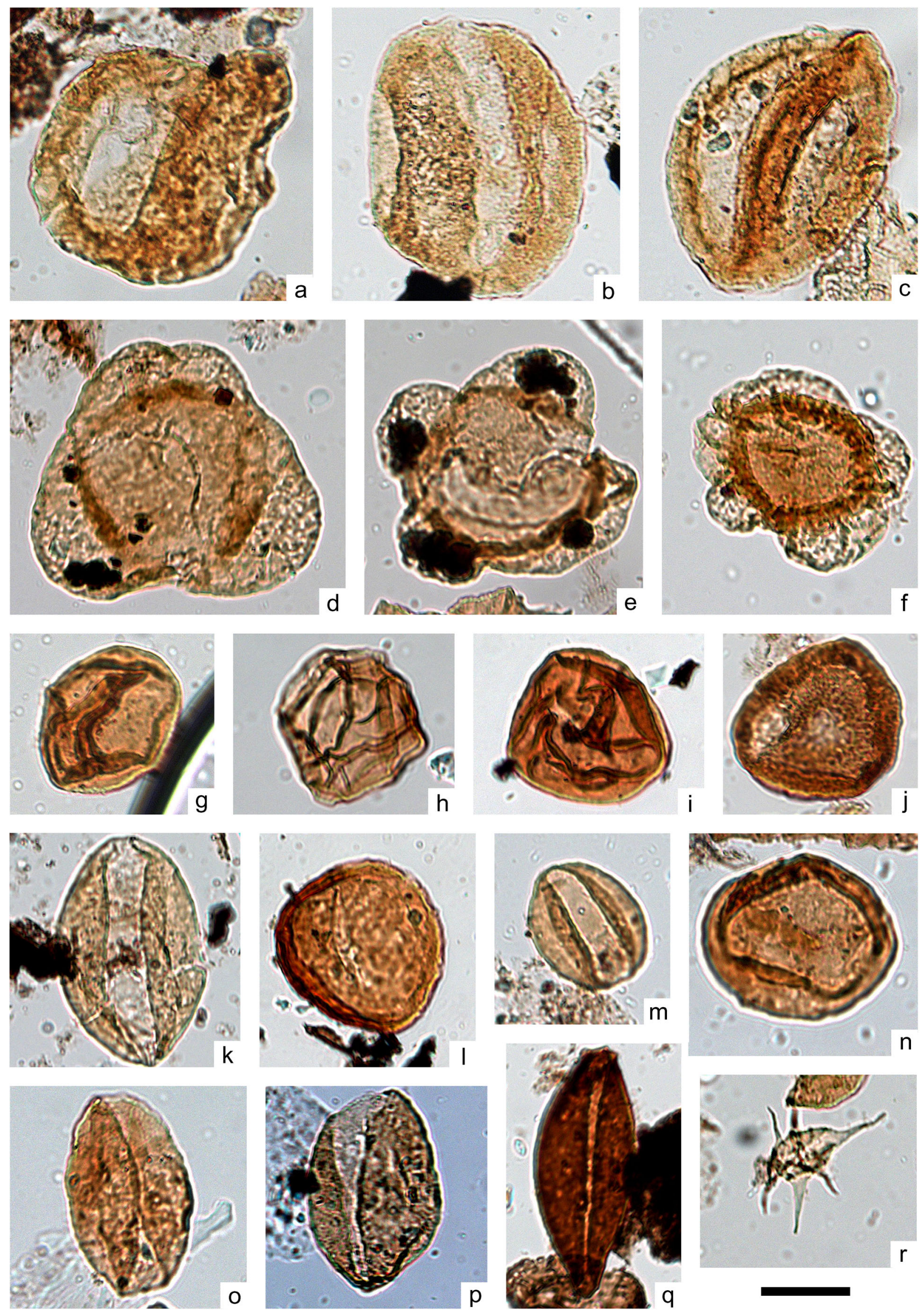


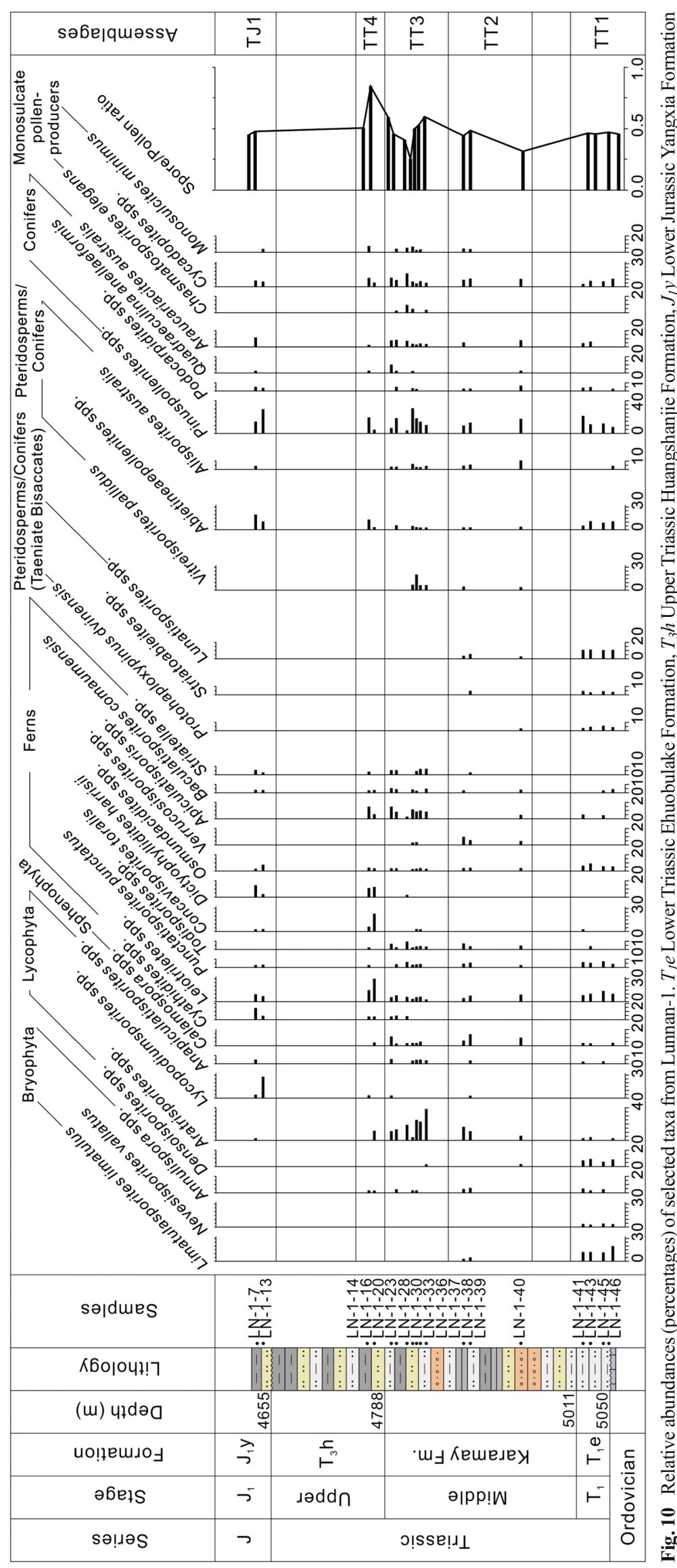




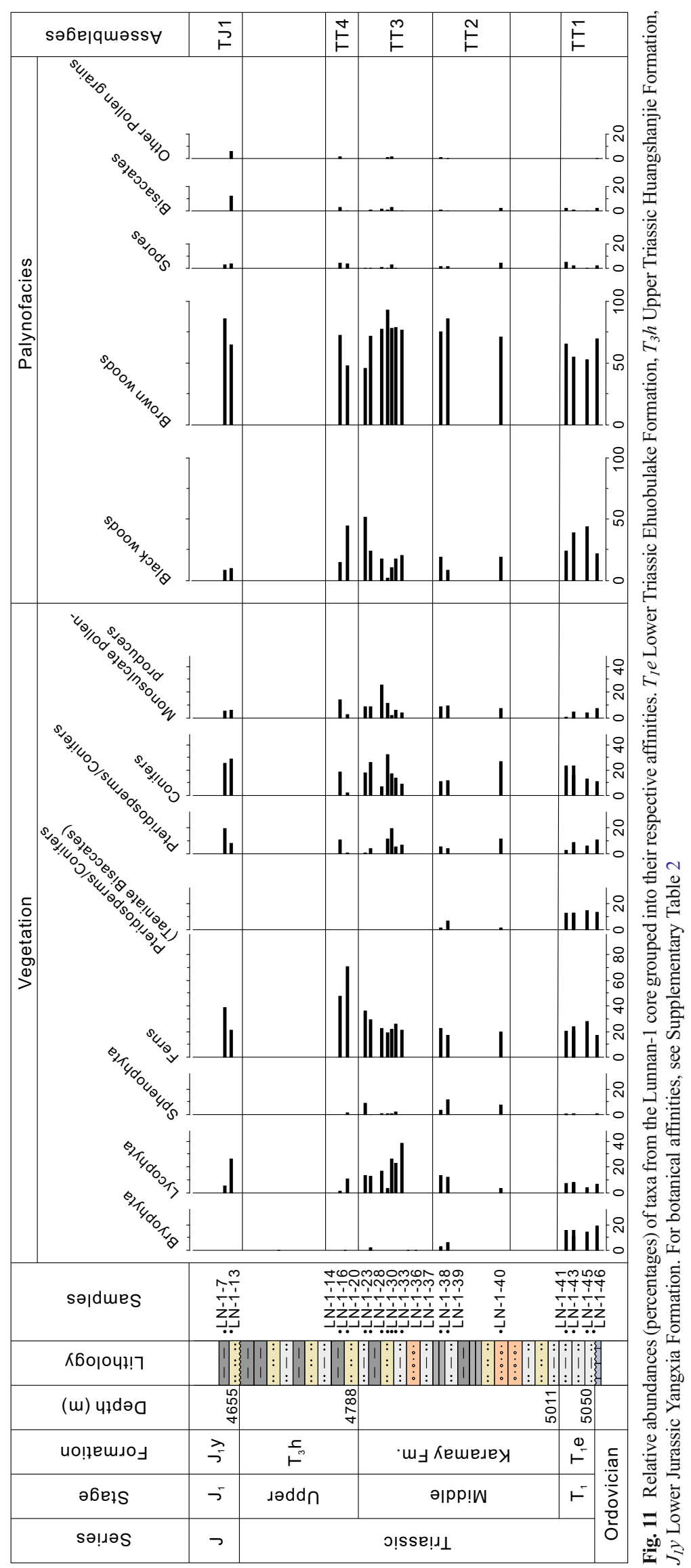




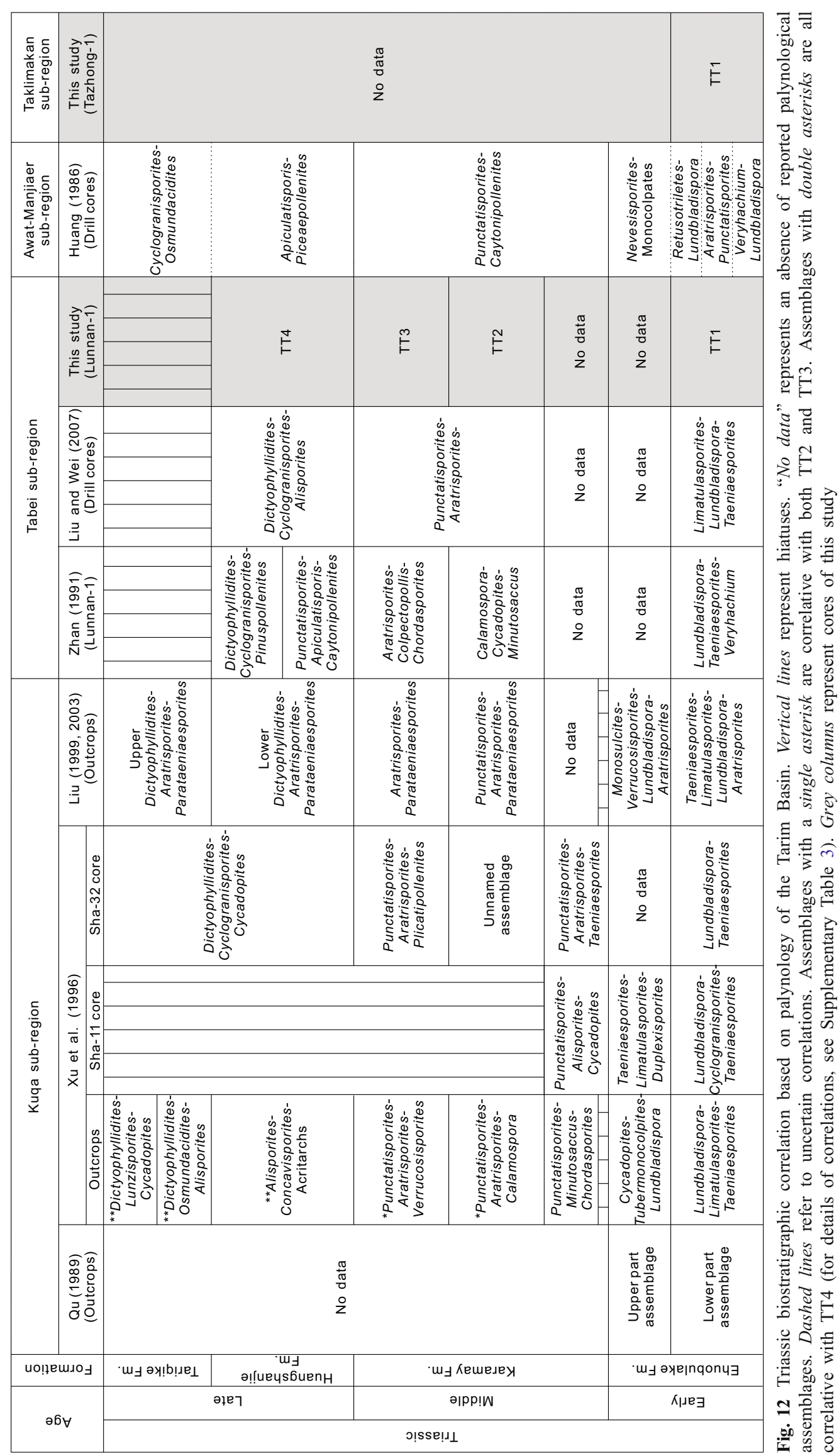


Fig. 13 Non-metric multidimensional scaling plot of spore-pollen relative abundance (percentage) data

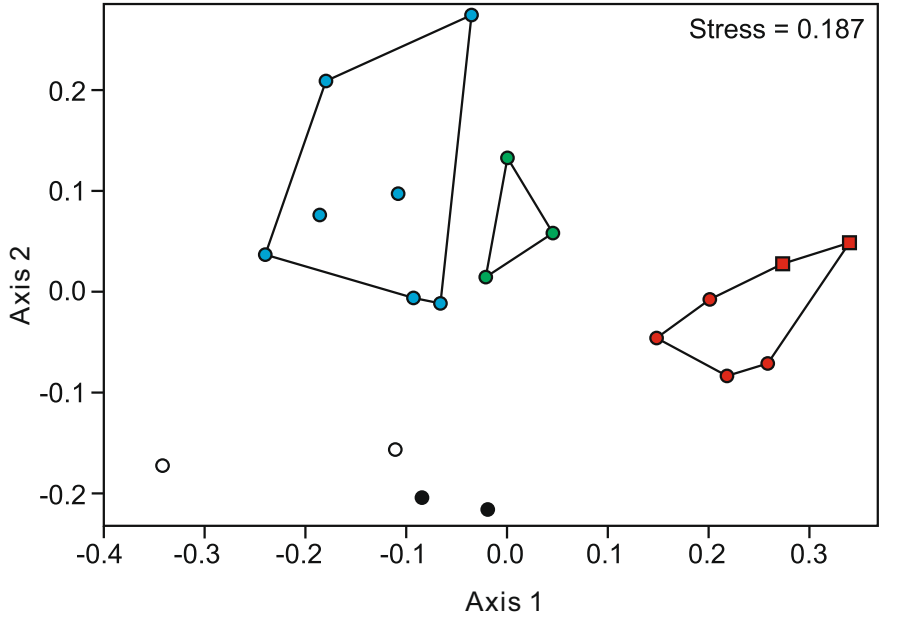

Lunnan-1

- TJ1 (Jurassic)

- TT4 (Upper Triassic)

- TT3 (upper Middle Triassic)

- TT2 (lower Middle Triassic)

- TT1 (Lower Triassic)

Tazhong-1

- TT1 (Lower Triassic) reflect the local climatic and/or habitat changes, considering the lack of a conformable "boundary". They also potentially represent local vegetation responses to the $\mathrm{T}-\mathrm{J}$ extinction, although spore/pollen peaks are typically recognised within or above extinction event intervals (e.g. Ruckwied et al. 2008; Ruckwied and Götz 2009; Larsson 2009; Götz et al. 2009, 2011; Vajda et al. 2013; Vajda and Bercovici 2014).

\section{Late Triassic palynofloral provinces of China}

Two Late Triassic palynofloral provinces encompassing North and South China, respectively, were proposed by Qu et al. (1983) and subsequently followed by numerous authors (e.g. Qu et al. 1987; Sun et al. 1995; Song et al. 2000; Liu 2003; Shang 1998, 2011). The South China province possesses several key taxa (e.g. Ovalipollis, Ricciisporites, Rhaetipollis, Camerosporites, Kyrtomisporites, Verrusaccus and Granosaccus) that are absent or in very low abundances in the North China Province, which is characterised by cosmopolitan taxa (e.g. Apiculatisporis and Striatella). Ovalipollis, Ricciisporites and Kyrtomisporites have been reported from the North China Province: (i) Jiang et al. (2006) recorded Ovalipollis from the Shaanxi province in low abundance (1\%) without presenting images, (ii) Chen (1998) documented Ricciisporites from the southwestern region of the Tarim Basin without statistics or images and (iii) Huang (1993) reported Kyrtomisporites from the northwestern region of the Junggar Basin in low abundances $(<1 \%)$ without presenting images. The very low abundances and scattered distribution of these important taxa await more information for confirmation.

The boundary between the North and South palynofloral provinces was considered to follow the "Palaeo-Kunlun Mountains, Palaeo-Qinling Mountains and Palaeo-Dabie Mountain" (Qu et al. 1983, 1987; Sun et al. 1995; Shang 1998, 2011; Song et al. 2000; i.e. the northern margin of the Tarim Basin according to their figures) based on palynological and macrofloral evidence. However, through assessment of the palynofloras of the Taxinan and Kuqa sub-regions (Liu 1996, 1999, 2003), this boundary was moved to the southern margin of this basin (Liu 2003) (solid line in Fig. 15). The present study provides additional information on phytogeographic affinity for the Late Triassic palynofloras of the Tarim Basin.

The Late Triassic palynoflora of the Tabei sub-region of the Tarim Basin (Lunnan-1) lacks key taxa typically present in the South China Province. This suggests that the Tabei sub-region of the Tarim Basin should be incorporated into the North China Province, which is similar to the marginal Kuqa sub-region studied by Liu (2003). It should be noted that no Late Triassic palynofloras have been recovered from the southern part of the Tarim Basin; hence, the phytogeographic affinity of the southern area of this basin is uncertain. Here, based on the new evidence from the Tabei sub-region, we tentatively regard the whole basin as a single Late Triassic phytogeographic region within the North China Province, with the boundary running along the southern margin of the Tarim Basin (Fig. 15). More data from the southern areas are required to explore the phytogeographic affinity of the whole basin and to resolve the precise position of the North-South palynofloral province boundary.

\section{Conclusions}

Well-preserved Triassic and Early Jurassic spore-pollen assemblages have been recovered from Lunnan-1 and 
Fig. 14 Vegetation reconstructions illustrating Early Triassic to Early Jurassic ecosystems of the Tarim Basin

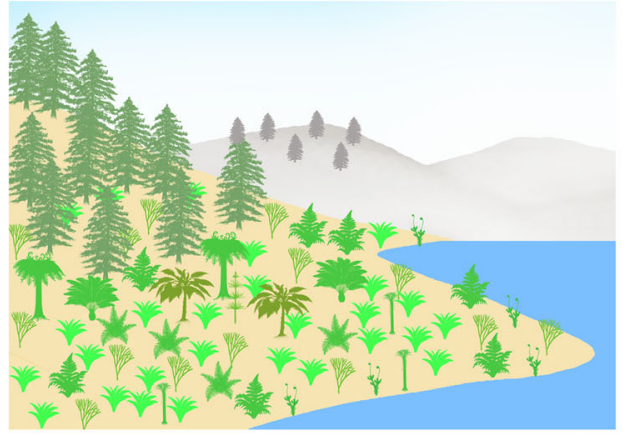

\section{Legend}
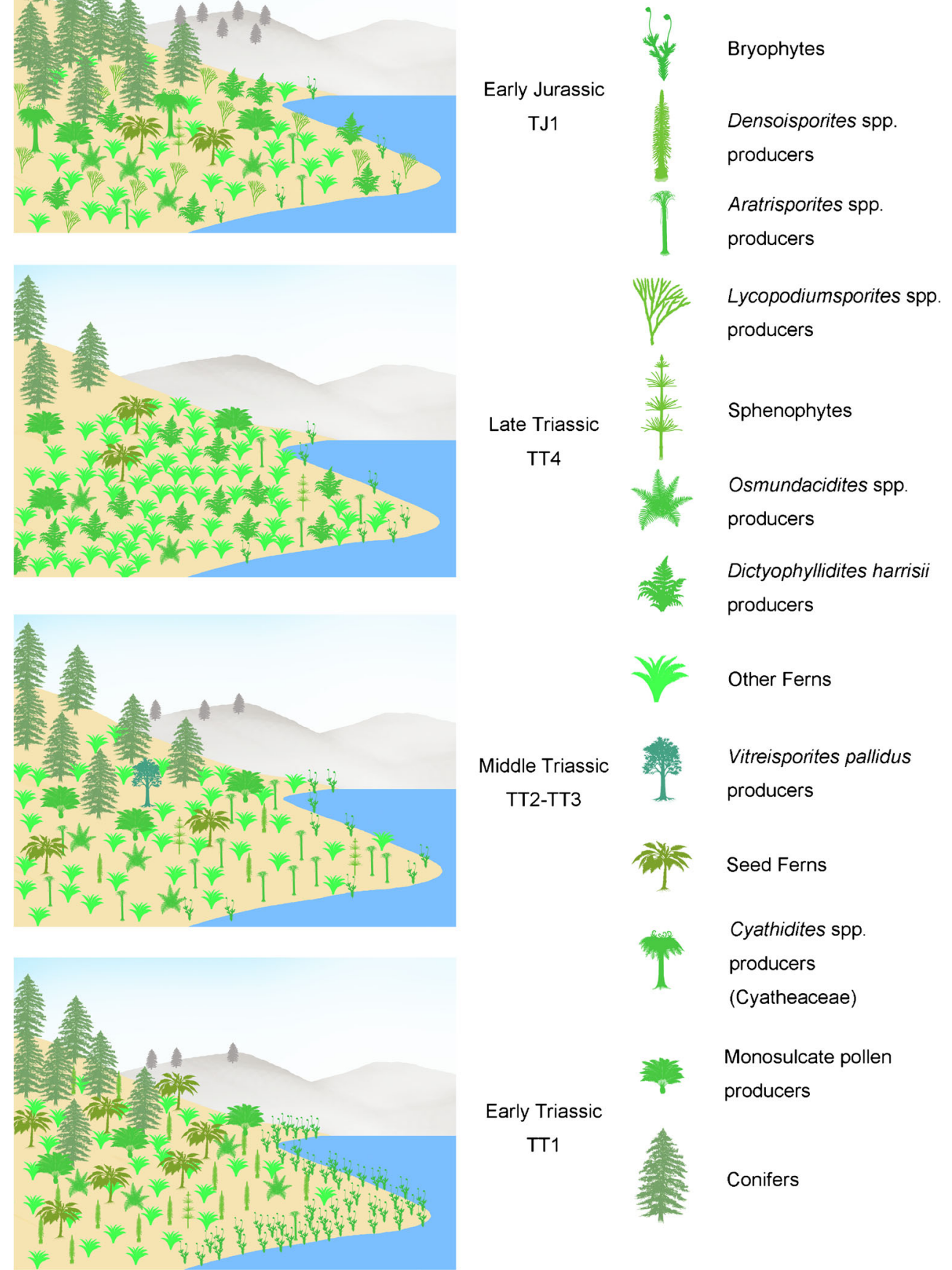

\section{producers}

(Cyatheaceae)

Monosulcate pollen

producers

Conifers
Tazhong-1 cores of the Tarim Basin, China. Through the sections, five palynological assemblages (TT1-TT4 and $\mathrm{TJ} 1$ ) were recognised based on compositional changes, supported by NMDS analysis. The age of the studied assemblages ranges from Early Triassic (Olenekian) to Early Jurassic. The vegetation reconstruction for the Triassic of the Tarim Basin shows that, based on palynology, the effects of two mass extinction events are reflected in the vegetation composition. The Early Triassic assemblages in the TT1 zone are characterised by abundant bryophytes and Densoisporites spp.-producers, a well-known marker for the Early Triassic recovery succession following the end-Permian event (Vajda and McLoughlin 2007). Two spore peaks recorded in the Upper Triassic and Lower 


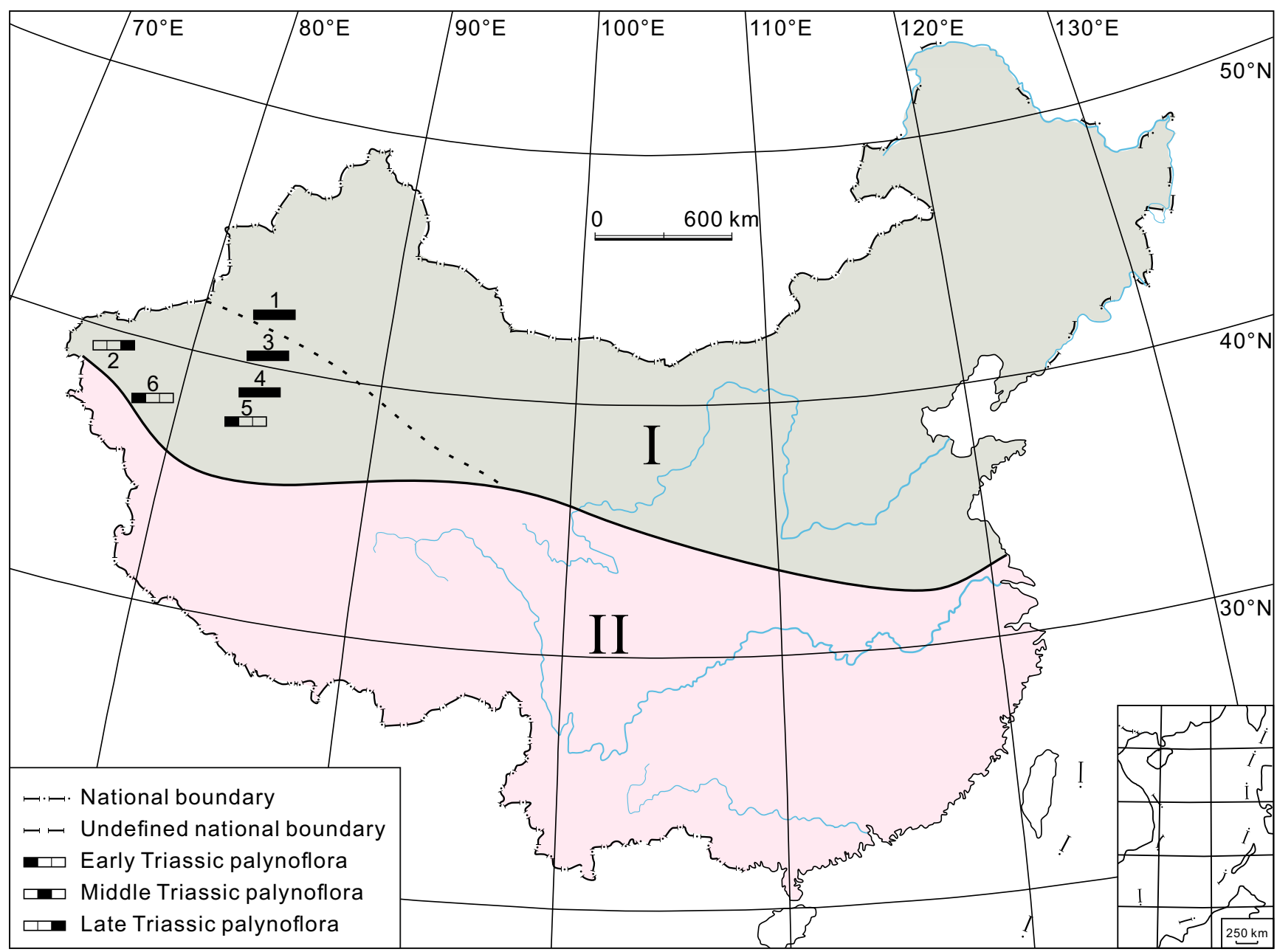

Fig. 15 Map showing different opinions on the boundary of the Late Triassic palynofloral provinces in China. Dashed line represents the interpretations of Sun et al. (1995) and Shang (1998, 2011). Solid line represents the suggestions of Liu (2003) and this study. I North China Province, II South China Province. 1 The Kuqa River Section in the Kuqa sub-region (Qu 1989; Xu et al. 1996; Liu 1999, 2003; Li et al. 2001). 2
Sections in the Taxinan sub-region (Chen 1998). 3 Core Lunnan-1 (Yong et al. 1990; Zhan 1991; Li et al. 2001; this study), cores Sha-11 and Sha32 (Xu et al. 1996) and four cores (Liu and Wei 2007) in the Tabei subregion. 4 Cores in the Awat-Manjiaer sub-region (Huang 1986). 5 The core Tazhong-1 (Li et al. 2001; this study) in the Taklimakan sub-region. 6 Sections in the Taxinan sub-region (Liu 1996; Li et al. 2001)
Jurassic potentially reflect vegetation responses to the $\mathrm{T}-\mathrm{J}$ extinction. However, the unconformable nature of this succession makes such interpretations tentative. Our phytogeographic analysis based on the palynological data shows that the Late Triassic palynofloras of the Tarim Basin are more similar to those of North China. This calls for an update of the boundaries of the regional vegetation provinces, and we support that the western section of the boundary between the North and South China palynofloras should follow the southern margin of the Tarim Basin.

Acknowledgements This work was supported by the Strategic Priority Research Program (B) of the Chinese Academy of Sciences (Grant No.: XDB03010103 and XDB18000000), the China Scholarship Council (201504910609) and the Swedish Research Council (Grant VR 2015-
04264). This is also a contribution of IGCP project 632 . We thank Pollyanna von Knorring for contributing to the landscape illustration (Fig. 14). Annette E. Götz and Mike Pole are gratefully acknowledged on their very constructive reviews that considerably improved the manuscript.

\section{Compliance with ethical standards}

Conflict of interest The authors declare that they have no conflict of interest.

Open Access This article is distributed under the terms of the Creative Commons Attribution 4.0 International License (http:// creativecommons.org/licenses/by/4.0/), which permits unrestricted use, distribution, and reproduction in any medium, provided you give appropriate credit to the original author(s) and the source, provide a link to the Creative Commons license, and indicate if changes were made. 


\section{References}

Akikuni, K., Hori, R., Vajda, V., Grant-Mackie, J., \& Ikehara, M. (2010). Stratigraphy of Triassic-Jurassic boundary sequences from the Kawhia coast and Awakino gorge, Murihiku Terrane, New Zealand. Stratigraphy, 7, 7-24.

Balme, B. E. (1995). Fossil in situ spores and pollen grains: an annotated catalogue. Review of Palaeobotany and Palynology, 87, 81-323.

Batten, D. J. (1996). Chapter 26A. Palynofacies and palaeoenvironmental interpretation. In J. Jansonius \& D. C. McGregor (Eds.), Palynology: principles and applications, 3 (pp. 1011-1064). Utah: Publisher Press.

Batten, D. J., \& Dutta, R. J. (1997). Ultrastructure of exine of gymnospermous pollen grains from Jurassic and basal Cretaceous deposits in Northwest Europe and implications for botanical relationships. Review of Palaeobotany and Palynology, 99, 25-54.

Batten, D. J., \& Grenfell, H. R. (1996). Chapter 7D. Botryococcus. In J. Jansonius \& D. C. McGregor (Eds.), Palynology: principles and applications, 1 (pp. 205-214). Utah: Publishers Press.

Bercovici, A., Cui, Y., Forel, M., Yu, J. X., \& Vajda, V. (2015). Terrestrial palaeoenvironment characterization across the Permian-Triassic boundary in South China. Journal of Asian Earth Sciences, 98, 225-246.

Bonis, N. R., \& Kürschner, W. M. (2012). Vegetation history, diversity patterns, and climate change across the Triassic/Jurassic boundary. Paleobiology, 38(2), 240-264.

Cao, Z. Y., Li, W. B., Liu, Z. S., Chen, J. H., Cao, M. Z., \& Xiao, S. H. (2001). Jurassic. In Z. Y. Zhou (Ed.), Stratigraphy of the Tarim Basin (pp. 236-260). Beijing: Science Press.

Carroll, A. R., Graham, S. A., Hendrix, M. S., Ying, D., \& Zhou, D. (1995). Late Paleozoic tectonic amalgamation of northwestern China: sedimentary record of the northern Tarim, northwestern Turpan, and southern Junggar Basins. Geological Society of America Bulletin, 107(5), 571-598.

Carroll, A. R., Graham, S. A., \& Smith, M. E. (2010). Walled sedimentary basins of China. Basin Research, 22, 17-32.

Césari, S. N., \& Colombi, C. E. (2016). Palynology of the Late Triassic Ischigualasto Formation, Argentina: paleoecological and palaeogeographic implications. Palaeogeography, Palaeoclimatology, Palaeoecology, 449, 365-384.

Chen, R. L. (1998). The discovery of Late Triassic strata and its geological significance in the southwestern Tarim Basin. Experimental Petroleum Geology, 20(4), 329-331.

Couper, R. A. (1958). British Mesozoic microspores and pollen grains. A systematic and stratigraphic study. Palaeontographica B, 103, 75179

Delcourt, A. F., Dettmann, M. E., \& Hughes, N. F. (1963). Revision of some Lower Cretaceous microspores from Belgium. Palaeontology, 6(2), 282-292.

Götz, A. E., Ruckwied, K., Pálfy, J., \& Haas, J. (2009). Palynological evidence of synchronous changes within the terrestrial and marine realm at the Triassic/Jurassic boundary (Csővár section, Hungary). Review of Palaeobotany and Palynology, 156, 401-409.

Götz, A. E., Ruckwied, K., \& Barbacka, M. (2011). Palaeoenvironment of the Late Triassic (Rhaetian) and Early Jurassic (Hettangian) Mecsek Coal Formation (south Hungary): implications from macro- and microfloral assemblages. Palaeobiodiversity and Palaeoenvironments, 91, 75-88

Grauvogel-Stamm, L., \& Ash, S. R. (2005). Recovery of the Triassic land flora from the end-Permian life crisis. Comptes Rendus Palevol, 4, 593-608.

Hammer, Ø., Harper, D. A. T., \& Ryan, P. D. (2001). PAST: paleontological statistics software package for education and data analysis. Palaeontologia Electronica, 4(1), 1-9.
Harrington, G. J. (2008). Comparisons between Palaeocene-Eocene paratropical swamp and marginal marine pollen floras from Alabama and Mississippi, USA. Palaeontology, 51, 611-622.

Helby, R., Morgan, R., \& Partridge, A. D. (1987). A palynological zonation of the Australian Mesozoic. In P. A. Jell (Ed.), Studies in Australian palynology (pp. 1-94). Sydney: Association of Australasian Palaeontologists.

Hermann, E., Hochuli, P. A., Bucher, H., Brühwiler, T., Hautmann, M., Ware, D., \& Roohi, G. (2011). Terrestrial ecosystems on North Gondwana following the end-Permian mass extinction. Gondwana Research, 20, 630-637.

Hochuli, P. A., Hermann, E., Vigran, J. O., Bucher, H., \& Weissert, H. (2010). Rapid demise and recovery of plant ecosystems across the end-Permian extinction event. Global and Planetary Change, 74, $144-155$.

Huang, P. (1993). Triassic sporopollen assemblages from northwestern margin of Junggar Basin, Xinjiang. Acta Micropalaeontologica Sinica, 10(4), 369-395.

Huang, Y. Y. (1986). Triassic system in the north part of Tarim Basin and its oil prospecting. Oil and Gas Geology, 7(1), 32-41.

Huang, Z. B., Wu, S. Z., Zhao, Z. X., Li, M., Tan, Z. J., \& Du, P. D. (2002). The composite regional stratigraphic classification in Tarim Basin and its circumferences. Xinjiang Petroleum Geology, 23(1), 13-17.

Jiang, D. X., Wang, Y. D., \& Wei, J. (2006). Palynoflora and its environmental significance of the Late Triassic in Tongchuan, Shaanxi Province. Journal of Palaeogeography, 8(1), 23-33.

Kang, Y. Z., \& Kang, Z. H. (1996). Tectonic evolution and oil and gas of Tarim basin. Journal of Southeast Asian Earth Sciences, 13(3-5), 317-325.

Larsson, L. M. (2009). Palynostratigraphy of the Triassic-Jurassic transition in southern Sweden. Geologiska Föreningen i Stockholm Förhandlingar, 131(1-2), 147-163.

Li, W. B. (1993). Kuqaia-a new palynomorph taxon. Acta Micropalaeontologica Sinica, 10(1), 71-76.

Li, J. G., \& Batten, D. J. (2005). Palynofacies: principles and methods. Acta Palaeontologica Sinica, 44(1), 138-156.

Li, W. B., Chen, J. H., Cao, Z. Y., Xiao, S. H., \& Cao, M. Z. (2001). Triassic. In Z. Y. Zhou (Ed.), Stratigraphy of the Tarim Basin (pp. 208-235). Beijing: Science Press.

Liu, Z. S. (1996). Biota and environment of Early Triassic in Duwa area of Tarim Basin. Xinjiang Petroleum Geology, 17(3), 242-254.

Liu, Z. S. (1999). Triassic palynological assemblages from the northern margin in Tarim Basin of Xinjiang, NW China. Acta Palaeontologica Sinica, 38(4), 474-504.

Liu, Z. S. (2003). Triassic and Jurassic sporopollen assemblage from the Kuqa depression, Tarim Basin of Xinjiang, NW China. Palaeontologia Sinica 190, New Series A, 14, 1-244.

Liu, G. S., \& Wei, L. (2007). Triassic palynological assemblages from Yuqi, Tarim Basin. Geology and Mineral Resources of South China, 2007(4), 56-63.

Liu, Z. S., Shang, Y. K., \& Li, W. B. (1981). Triassic and Jurassic sporopollen assemblages from some localities of Shaanxi and Gansu, North-West China. Bulletin of Nanjing Institute of Geology and Palaeontology, Academia Sinica, 3, 131-210.

Looy, C. V., Brugman, W. A., Dilcher, D. L., \& Visscher, H. (1999). The delayed resurgence of equatorial forests after the Permian-Triassic ecologic crisis. Proceedings of the National Academy of Sciences of the United States of America, 96(24), 13857-13862.

Mander, L. (2011). Taxonomic resolution of the Triassic-Jurassic sporomorph record in East Greenland. Journal of Micropalaeontology, $30,107-118$.

Mander, L., Kürschner, W. M., \& McElwain, J. C. (2010). An explanation for conflicting records of Triassic-Jurassic plant diversity. Proceedings of the National Academy of Sciences of the United States of America, 107(35), 15351-15356. 
McElwain, J. C., Wagner, P. J., \& Hesselbo, S. P. (2009). Fossil plant relative abundances indicate sudden loss of Late Triassic biodiversity in East Greenland. Science, 324, 1554-1556.

$\mathrm{Qu}, \mathrm{L}$. F. (1980). Triassic spores and pollen. In Institute of Geology, Chinese Academy of Geological Sciences (Ed.), Mesozoic stratigraphy and palaeontology of the Shaanxi-Gansu-Ningxia Basin (pp. 115-143). Beijing: Geological Publishing House.

Qu, L. F. (1989). Early Triassic sporo-pollen. In Institute of Geology and Mineral, Xinjiang Bureau of Geology \& Mineral Resources, Institute of Geology, Chinese Academy of Geological Sciences (Eds.), Research on the boundary between Permian and Triassic in Tianshan Mountain of China (pp. 36-39). Beijing: China Ocean Press.

Qu, L. F., \& Wang, Z. (1986). Triassic sporopollen. In Institute of Geology, Chinese Academy of Geological Sciences \& Institute of Geology, Xinjiang Bureau of Geology and Mineral Resources (Eds.), Permian and Triassic strata and fossil assemblages in the Dalongkou area of Jimsar, Xinjiang (pp. 111-173). Beijing: Geological Publishing House.

Qu, L. F., \& Wang, Z. (1990). Triassic palynological assemblages in North Xinjiang. In Institute of Geology, Chinese Academy of Geological Sciences \& Research Institute of Petroleum Exploration and Development, Xinjiang Petroleum Administration (Eds.), Permian to tertiary strata and palynological assemblages in the north of Xinjiang (pp. 37-56). Beijing: China Environmental Science Press.

Qu, L. F., Yang, J. D., Bai, Y. H., \& Zhang, Z. L. (1983). A preliminary discussion on the characteristics and stratigraphic division of Triassic spores and pollen in China. Bulletin of the Chinese Academy of Geological Science, 5, 81-94.

Qu, L. F., Zhang, W. P., \& Yu, J. X. (1987). Advance in Mesozoic palynological researches for thirty years. Professional Papers of Stratigraphy and Palaeontology, 17, 65-91.

Raine, J. I., Mildenhall, D. C., \& Kennedy, E. M. (2011). New Zealand fossil spores and pollen: an illustrated catalogue, 4th edition. GNS Science miscellaneous series no. 4. http://data.gns.cri.nz/ sporepollen/index.htm.

Rouse, G. E. (1957). The application of a new nomenclatural approach to Upper Cretaceous plant microfossils from Western Canada. Canadian Journal of Botany, 35, 349-375.

Ruckwied, K., Götz, A. E., Pálfy, J., \& Török, Á. (2008). Palynology of a terrestrial coal-bearing series across the Triassic/Jurassic boundary (Mecsek Mts, Hungary). Central European Geology, 51(1), 1-15.

Ruckwied, K., \& Götz, A. E. (2009). Climate change at the Triassic/ Jurassic boundary: palynological evidence from the Furkaska section (Tatra Mountains, Slovakia). Geological Carpathica, 60(2), 139-149.

Sha, J. G., Vajda, V., Pan, Y. H., Larsson, L., Yao, X. G., Zhang, X. L., Wang, Y. Q., Cheng, X. S., Jiang, B. Y., Deng, S. H., Chen, S. W., \& Peng, B. (2011). Stratigraphy of the Triassic-Jurassic boundary succession of the southern margin of the Junggar Basin, northwestern China. Acta Geologica Sinica, 85(2), 421-436.

Sha, J. G., Olsen, P. E., Pan, Y. H., Xu, D. Y., Wang, Y. Q., Zhang, X. L., Yao, X. G., \& Vajda, V. (2015). Triassic-Jurassic climate in continental high-latitude Asia was dominated by obliquity-paced variations (Junggar Basin, Ürümqi, China). Proceedings of the National Academy of Sciences of the United States of America, 112(12), 3624-3629.

Shang, Y. K. (1998). Late Triassic palynoflora provinces of China. Acta Palaeontologica Sinica, 37(4), 427-445.

Shang, Y. K. (2011). Late Triassic palynology of Yunnan and Guizhou, China. Palaeontologica Sinica 196, New Series A, 16, 1-276.

Shen, S. Z., Crowley, J. L., Wang, Y., Bowring, S. A., Erwin, D. H., Sadler, P. M., Cao, C. Q., Rothman, D. H., Henderson, C. M.,
Ramezani, J., Zhang, H., Shen, Y. A., Wang, X. D., Wang, W., Mu, L., Li, W. Z., Tang, Y. G., Liu, X. L., Liu, L. J., Zeng, Y., Jiang, Y. F., \& Jin, Y. G. (2011). Calibrating the end-Permian mass extinction. Science, 334, 1367-1372.

Slater, S. M., \& Wellman, C. H. (2015). A quantitative comparison of dispersed spore/pollen and plant megafossil assemblages from a Middle Jurassic plant bed from Yorkshire, UK. Paleobiology, 4(4), 640-660.

Slater, S. M., \& Wellman, C. H. (2016). Middle Jurassic vegetation dynamics based on quantitative analysis of spore/pollen assemblages from the Ravenscar Group, North Yorkshire, UK. Palaeontology, 59(2), 309-328.

Song, Z. C., Shang, Y. K., Liu, Z. S., Huang, P., Wang, X. F., Qian, L. J., Du, B. A., \& Zhang, D. H. (2000). Fossil spores and pollen of China, 2: the Mesozoic spores and pollen (pp. 1-170). Beijing: Science Press.

Sun, G., Meng, F. S., Qian, L. J., \& Ouyang, S. (1995). Triassic floras. In X. X. Li (Ed.), Fossil floras of China through the geological ages (pp. 305-342). Guangzhou: Guangdong Science and Technology Publishing House.

van de Schootbrugge, B., Quan, T. M., Lindström, S., Püttmann, W., Heunisch, C., Pross, J., Fiebig, J., Petschick, R., Röhling, H.-G., Richoz, S., Rosenthal, Y., \& Falkowski, P. G. (2009). Floral changes across the Triassic/Jurassic boundary linked to flood basalt volcanism. Nature Geoscience, 2, 589-594.

van Konijnenburg-van Cittert, J. H. A. (1993). A review of the Matoniaceae based on in situ spores. Review of Palaeobotany and Palynology, 78, 235-267.

Vajda, V., \& McLoughlin, S. (2007). Extinction and recovery patterns of the vegetation across the Cretaceous-Palaeogene boundary - a tool for unravelling the causes of the end-Permian mass-extinction. Review of Palaeobotany and Palynology, 144, 99-112.

Vajda, V., Calner, M., \& Ahlberg, A. (2013). Palynostratigraphy of dinosaur footprint-bearing deposits from the Triassic-Jurassic boundary interval of Sweden. Geologiska Föreningen i Stockholm Förhandlingar., 135(1), 120-130.

Vajda, V., \& Bercovici, A. (2014). The global vegetation pattern across the Cretaceous-Palaeogene mass extinction interval: a template for other extinction events. Global and Planetary Change, 122, 29-49.

Wang, Q. M., Nishidai, T., \& Coward, M. P. (1992). The Tarim Basin, NW China: formation and aspects of petroleum geology. Journal of Petroleum Geology, 15(1), 5-34.

Xu, Y. L., Yang, G. D., \& Zhao, Y. Y. (1996). Triassic palynology and division of sequence stratigraphy from northern Tarim Basin. Geoscience, 10(4), 437-447.

Yong, T. S., Song, L. X., Yu, Y. D., \& Yu, X. Q. (1990). The Mesozoic stratum of the well Lunnan-1 in Tarim Basin. Xinjiang Petroleum Geology, 11(2), 132-135.

Zhan, J. Z. (1991). The Mesozoic stratigraphic divisions from the well Lunnan no. 1 and its fossil evidences. Xinjiang Petroleum Geology, 12(4), 293-300.

Zhang, S. C., Hanson, A. D., Moldowan, J. M., Graham, S. A., Liang, D. G., Chang, E., \& Fago, F. (2000). Paleozoic oil-source rock correlations in the Tarim Basin, NW China. Organic Geochemistry, 31, 273-286.

Zhang, S. B., Huang, Z. B., Zhu, H. C., et al. (2004). Subsurface Phanerozoic stratigraphy of the Tarim Basin (pp. 1-300). Beijing: Petroleum Industry Press.

Zhang, C. L., Zou, H. B., Li, H. K., \& Wang, H. Y. (2013). Tectonic framework and evolution of the Tarim Block in NW China. Gondwana Research, 23, 1306-1315.

Zhu, H. C. (1996). Discovery of the earliest Triassic spores and pollen from southwest Tarim and Permian-Triassic (P-T) boundary. Chinese Science Bulletin, 41(24), 2066-2069. 